\title{
MIXING ANALYSIS OF NUTRIENTS, OXYGEN AND INORGANIC CARBON IN THE CANARY ISLANDS REGION
}

Fiz F. Pérez*, Ludger Mintrop ${ }^{+}$, Octavio Llinás ${ }^{\S}$, Melchor Glez-Dávila*, Carmen G. Castro*, Arne Koertzinger ${ }^{+}$, Magdalena Santana-Casiano ${ }^{\#}$, Marta Alvarez ${ }^{*}$, M.J. Rueda ${ }^{\S}$,Aida F. Ríos*

*Instituto de Investigacións Mariñas de Vigo (CSIC),Eduardo Cabello, 6 , 36208 Vigo (SPAIN) ${ }^{+}$Abteilung Meereschemie, Institut für Meereskunde an der Universität Kiel, Düsternbrooker Weg 20, 24105 Kiel, Germany.

${ }^{\S}$ Instituto Canario de Ciencias Marinas, Aptdo 56, 35200 TELDE Gran Canaria (SPAIN) "Departamento de Quimica, Universidad de Las Palmas de Gran Canaria, Campus de Tafira, 35017 Las Palmas, Spain

email: fiz@iim.csic.es 


\section{ABSTRACT}

We show the distribution of nutrients, oxygen, total dissolved inorganic carbon $\left(\mathrm{C}_{\mathrm{T}}\right)$ and total alkalinity $\left(\mathrm{A}_{\mathrm{T}}\right)$ along three sections close to the Canary Islands, between $18^{\circ} \mathrm{W}$ and the African coast during Meteor 37/2 cruise (January 1997). From the thermohaline properties of Eastern North Atlantic Central Water, Mediterranean Water, Antarctic Intermediate Water (AAIW) and North Atlantic Deep Water- a mixing model has been established, based on the water mass description. It can explain most of the variability found in the distribution of the chemical variables, including the carbon system, and it is validated through the use of conservative chemical variables like 'NO'. From nutrients, oxygen, $A_{T}$ and $C_{T}$, the chemical characterisation of the water masses was performed calculating the concentration of these variables in the previously defined thermohaline end-members. The relative variation of nutrient concentrations, resulting from the regeneration of organic matter, was estimated. Close to the African shelf-break, a poleward undercurrent conveying as much as a $11 \%$ of AAIW was observed only in the southern section $\left(28.5^{\circ} \mathrm{N}\right)$. From the chemical and thermohaline properties of the end-members a comparison with data from other oceanic regions was made in respect to conservative chemical variables ('NO'). In addition, a north-south gradient in the ventilation pattern of water masses is observed, from the residuals of the model. 


\section{INTRODUCTION}

Under the framework of the multidisciplinary European project CANIGO (Canary Islands Azores Gibraltar Observations) the oceanographic cruise Meteor 37/2 was conducted on January 1997. The main objectives of this project were to investigate and model the circulation of the water masses in Subtropical Eastern North Atlantic and determine the fluxes of the different biogeochemical variables in this region.

The area north of the Canary Islands $\left(\sim 28^{\circ} \mathrm{N}\right)$ and south of Madeira Island $\left(\sim 33^{\circ} \mathrm{N}\right)$ is characterised in the upper layers by recirculating branches of the North Atlantic's Subtropical Gyre that feed the Canary Current and that are influenced by upwelling events off the African coast (Stramma and Müller, 1989). The region encompasses the eastern boundary current system. The flow field, the water mass transports and the associated biogeochemical fluxes in the region are strongly influenced by both, the recirculation of the subtropical gyre that feeds the Canary Current and the seasonally varying trade wind field with its impact on the upwelling system and the eastern boundary current system off North West Africa.

The thermohaline properties of water masses involved in the water column in the Eastern North Atlantic had been extensively described in previous studies (Harvey, 1982; McCartney and Talley, 1982; Fiuza, 1984; Käse et al., 1986; Pollard and Pu, 1985, Ríos et al. 1992, Arhan et al.,1994). In the upper ocean of the Azores region, two varieties of Eastern North Atlantic Central Water (ENACW) (Harvey, 1982; McCartney and Talley, 1982; Ríos et al., 1992): ENACWt (Eastern North Atlantic Water of subtropical origin) and ENACWp (Eastern North Atlantic Water of subpolar origin) are involved at different isopycnal levels. At deeper levels, the characteristic salinity minimum of AAIW formed at the Subantarctic Front, is detected northward up to $20^{\circ} \mathrm{N}$ (Reid, 1994). The salinity minimum $(\mathrm{S}<35.4)$ detected by Ríos et al. (1992) at $24^{\circ} \mathrm{N}$ and $22^{\circ} \mathrm{W}$ can be ascribed to influence of AAIW according to Willenbrink (1982). Tsuchiya (1989) suggested further northward penetration, up to $47^{\circ} \mathrm{N}$, of AAIW traced by a maximum of silicate. However, this maximum could also be due to biogeochemical processes in the water column. In this sense, below the ENACW, the penetration and influence 
of Mediterranean Water (MW) is prevalent down to 2000m in the North Atlantic (Reid, 1994). Below MW, Käse et al. (1986) reported the influence of Labrador Sea Water (LSW). The LSW reaches the African coast after a long excursion along a cyclonic gyre $\left(33-47^{\circ} \mathrm{N}\right)$ and a substantial mixing with MW (Reid, 1994; Paillet et al., 1998). Below LSW, the presence of North Atlantic Deep Water (NADW) is detected by the small variability and linearity in the thermohaline structure and the high silicate content (Arhan et al. 1994, Castro et al. 1998). The strong vertical gradient in silicate concentration is due to the downward increasing influence of Antarctic Bottom Water (Stoll et al. 1996). Harvey and Arhan (1988) and Rhein and Hinrichsen (1993) suggest the mixing of NADW and MW. Broecker and Takahashi (1980), Le Tourbillon group (1983) and Kawase and Sarmiento (1986) also point out the possibility of enhanced mixing by a salt finger mechanism.

Here we combined the thermohaline and chemical properties to study the chemical variability of the water masses is the Subtropical Eastern North Atlantic, with specially emphasis on the ventilation and ageing pattern. From the water masses variability followed from the thermohaline distribution, several mixing models can been used to quantify the variability of both nutrients and oxygen. One of the most widely used techniques is that of working along isopycnic layers assuming only the existence of lateral mixing (Takahashi et al., 1985; Kawase and Sarmiento, 1986). However, in areas of subduction or upwelling, the vertical advection excludes to allow for any restriction in the modelling of nutrients (Broenkow, 1965; Minas et al., 1982). Tomczak (1981) developed the analysis of sea water masses from mixing triangles without assumption of isopycnal mixing. This kind of analysis can only resolve mixing from three end-members, considering that only salinity and temperature will be used as conservative variables, as has been recently shown for the North Atlantic (Pérez et al. 1993; Castro et al. 1998; Pérez et al. 1998). Each of the three water mass end-member is defined by a single and fixed temperature and salinity, while a water mass is conventionally characterised by the mixing of only two end-members, therefore showing a rather fixed TS relationship. 
In general, dissolved oxygen and nutrient distributions do not behave in a conservative way, due to biological activity. However, it is possible to remove the effect of these processes by knowing the average chemical relations. Broecker (1974) brought forward the concept of 'NO' ('NO' $=\mathrm{R}_{\mathrm{N}} \cdot \mathrm{NO}_{3}+\mathrm{O}_{2}$ ), a conservative tracer which balances the effect of nutrient regeneration by the associated oxygen consumption. His proposed $R_{N}\left(=-\Delta \mathrm{O}_{2}: \Delta N \mathrm{~N}_{3}\right)$ factor was 9, but a set of different values has been reported in the literature proposed by others, varying between 9 and 10.5 (Redfield et al., 1963; Takahashi et al., 1985; Minster and Boulahdid, 1987; Ríos et al., 1989, Pérez et al. 1993). However, 9.33 was the value most frequently derived by different procedures and from various data sets (Minster and Boulahdid, 1987; Anderson 1995; Fraga et al. 1999) and it is in agreement with the average chemical composition of phytoplankton (Fraga and Pérez, 1990; Laws, 1991). The regeneration of organic matter also increases the total inorganic carbon $\left(\mathrm{C}_{\mathrm{T}}\right)$, and thus a similar conservative tracer can be defined ('CO') using the stoichiometric ratio $\mathrm{R}_{\mathrm{C}}\left(=\Delta \mathrm{O}_{2}: \Delta \mathrm{C}_{\mathrm{T}}\right)$ which varies in a range from 1.05 to 1.58 (Fraga et al. 1998).

Several multiparametrical models, assuming a conservative behaviour for nutrient, have been used to resolve mixing of more than three end-members (Mackas et al., 1987, Tomczak and Large, 1989). In multivariate analyses, where both, conservative (S, $\theta$, 'NO') and non conservative variables (nutrients, oxygen, $\mathrm{C}_{T}$ and $\mathrm{A}_{T}$ ) are handled in the same way, it cannot be discerned which part of the nutrient content is due to remineralization or ventilation processes. In this sense, any variability in the non-conservative tracer could lead to an incorrect definition of new water mass types in areas of very intense biological activity. Alternatively, if the profile of water masses is completely well defined by the thermohaline variability, it is possible to define a mixing model that is based on a set of vertically ordered mixing triangles. This mixing model can be tested with other conservative tracer as 'NO'. Using the observed nonconservative chemical variables, this model allows the chemical characterisation of the water masses involved and the description of the ventilation and remineralization patterns (Pérez et al. 1993, Castro et al. 1998, Pérez et al. 1998). 
In this work, a mixing model was developed based on different water masses and their temperature and salinity distribution. The model explains most of chemical variability (nutrient, oxygen, alkalinity and $\mathrm{C}_{\mathrm{T}}$ ) of the water masses. This was tested by application of the conservative chemical tracers. The model residuals allow us to describe the ventilation/ageing pattern of the water masses in the study area. The chemical characterisation, including the carbon system, of the water masses will be done and an extensive comparison with other previous chemical characterisation of the water masses in the European basin of the North Atlantic will be shown. Special emphasis will be paid in the spreading of AAIW, in order to quantify and clarify the actual importance of the AAIW in the basin.

\section{MATERIAL AND METHODS}

During F.S. METEOR cruise 37, leg 2a (January 7 to 20, 1997), a hydrographic box (CANIGO box) was sampled north-west of the African coast. The box basically consists of three CTD/rosette sections: the first ran almost zonally from the African coast to a position north of La Palma Island at $29^{\circ} 10^{\prime} \mathrm{N}, 18^{\circ} 00^{\prime} \mathrm{W}$, the second went meridionally towards Madeira Island until $32^{\circ} 15^{\prime} \mathrm{N}$, the third then zonally towards the shelf until the $100 \mathrm{~m}$ bottom line was reached (Fig 1). A total of 26 biogeochemical stations were completed on these three sections. Each station consisted of two CTD/rosette-24bottles cast (shallow and bottom deep) with discrete sampling for dissolved oxygen, nutrients, chlorophyll, $\mathrm{pH}$ and several samples for alkalinity $\left(\mathrm{A}_{T}\right)$ and total inorganic carbon $\left(\mathrm{C}_{T}\right)$ at selected depths: $10,25,50,75,100,125,150$, $200,250,300,350,400,500,600,700,800,1000,1100,1250$ and every $250 \mathrm{~m}$ to the bottom, including one 20 meters above the seafloor.

A Neil Brown MKIIIB CTD was used to obtain continuous profiles of temperature and salinity. The CTD's pressure and temperature sensors were calibrated in the laboratory against WOCE standards. The conductivity sensor was calibrated by comparison with the in-situ conductivity of bottle samples taken during the upward profile with the rosette. CTD data processing and removal of typical non-linear effects in sensor responses was performed following Müller et al. (1995). The salinity samples were analysed with a Guildline AUTOSAL 
salinometer with an accuracy better than 0.002 for single samples.

Dissolved oxygen was measured using an automated potentiometric modification of the original Winkler method following WOCE standards (WOCE, 1994). The standard error for five replicates was less than $2 \mu \mathrm{mol} \cdot \mathrm{kg}^{-1}$ (Llinás et al., 1997). The Apparent Oxygen Utilisation (AOU) defined as the deficit of oxygen concentration relative to the atmospheric saturation (UNESCO, 1986) is used to describe the oxygen distribution. Samples for nutrient analysis were frozen at $-20^{\circ} \mathrm{C}$ and then analysed at the ICCM also following WOCE standards (WOCE, 1994). Nutrients were determined by colorimetric methods, using a Technicon AutoAnalyzer AAII. For silicates, a modified Hansen and Grasshoff (1983) method was used, in which ßsilicomolybdenic acid is reduced with ascorbic acid. Nitrate was determined after reduction to nitrite in a Cd-Cu column. The standard deviation for duplicates was $0.07 \mu \mathrm{mol} \cdot \mathrm{kg}^{-1}$ for silicate, $0.06 \mu \mathrm{mol} \cdot \mathrm{kg}^{-1}$ for nitrate and $0.01 \mu \mathrm{mol} \cdot \mathrm{kg}^{-1}$ for phosphate. This is equivalent to $0.3 \%, 0.5 \%$ and $0.8 \%$ at full scale, respectively.

A coulometric titration technique was used for determining $\mathrm{C}_{\mathrm{T}}$ (SOMMA-system, Johnson et al., 1993; DOE, 1994). The SOMMA was calibrated with pure $\mathrm{CO}_{2}$ and tested by running different batches of Certified Reference Material (CRM, provided by A. Dickson, SIO, La Jolla, CA, U.S.A.). The precision (between-bottle reproducibility) as judged from regular measurements of duplicate samples was $0.5 \mu \mathrm{mol} \cdot \mathrm{kg}^{-1}$. Accuracy of the data has been estimated to be about $1.5 \mu \mathrm{mol} \cdot \mathrm{kg}^{-1}$.

A Ross Orion 81-04 electrode (Orion Research Inc., Boston, Massachusetts, USA) calibrated with 7.413 NBS buffer, was used to determine pH (NBS-scale). The temperature was measured by a Pt-100 probe. All $\mathrm{pH}$ values refer to $15^{\circ} \mathrm{C}$ to avoid the temperature effect of $\mathrm{pH}$ (Pérez and Fraga, 1987). The same CRMs used for $\mathrm{C}_{\mathrm{T}}$ determinations were also used to monitor $\mathrm{pH}$ measurements. Parallel measurements of $\mathrm{pH}_{\mathrm{sws}}$ at $25^{\circ} \mathrm{C}$ yielded very good agreement with an average deviation of $(0.002 \pm 0.007)$ and a high correlation $\left(\mathrm{r}^{2}=0.99\right)$. All $\mathrm{pH}$ data was transformed into the SWS scale ( $\left.\mathrm{pH}_{\mathrm{SwS}}\right)$.

The determination of alkalinity by closed cell titration was performed with two separate 
potentiometric systems in parallel. The titration systems consist of two titrator type Titrino 702SM and 719S (Metrohm, Herisau, Switzerland), respectively: The electrodes used were a Ross glass pH electrode and a double junction silver/silver chloride reference electrode (Orion Research Inc., Boston, Massachusetts, USA). The acid in a water-jacketed burette and the seawater sample in a water-jacketed cell were maintained at $25 \pm 0.1^{\circ} \mathrm{C}$ using a constant temperature bath. The titration was performed by stepwise adding $\mathrm{HCl}$ to the seawater past the carbonic acid end point. A full titration takes about 20 minutes. The $\mathrm{HCl}$ solution (25 L, 0.25 M) was made up from concentrated analytical grade HCl (Merck, Darmstadt, Germany) in 0.45 $\mathrm{M} \mathrm{NaCl}$, in order to yield an ionic strength similar to open ocean seawater. The acid was standardized by titrating weighed amounts of $\mathrm{Na}_{2} \mathrm{CO}_{3}$ dissolved in $0.7 \mathrm{M} \mathrm{NaCl}$ solutions. The acid factor was also determined by coulometry with an agreement of $\pm 0.0001 \mathrm{M}$. The precision is better than $0.4 \mu \mathrm{mol} . \mathrm{kg}^{-1}$. The performance has been checked by titrating different batches of CRMs (\#32, \#34, \#35). An adjustment of the acid factor from $0.2504 \mathrm{M}$ to $0.2505 \mathrm{M}$ gave a better agreement with the certified values and was used in the computation of $A_{T}$.

\section{RESULTS AND DISCUSSION}

Distribution of nutrients and water masses.

A composite section, instead of three separate sections, here is used to resume the thermohaline and chemical distribution in the three sampled transects (Fig. 2). The African coast therefore is at both ends of the plot, and the $18^{\circ} \mathrm{W}$ section is then situated at about the centre. The depth axis was modified using three different scales (0-1000, 1000-2000 and 2000-bottom). in order to better resolved the upper $2000 \mathrm{~m}$. The upper salinity minimum centred at about $750 \mathrm{~m}$ depth is the lower end of the ENACW, which is characterised by a steady and strong gradient in salinity and temperature in the main thermocline. The isohaline of 35.66 defines the limit that separates the saline ENACWt from the fresher ENACWp (Harvey, 1982; Pollard et Pu, 1985). This isohaline closely follows the $12^{\circ} \mathrm{C}$ isotherm. So the ENACWt layer extends from the bottom of the surface layer down to 500m. Below it, down to the salinity minimum of ENACW, 
there is a relatively narrow layer of ENACWp. The minimum of salinity is lower than 35.4 in the south-east corner at $800 \mathrm{~m}$ depth, between Lanzarote Island and the African shelf, tracing the northward advection of AAIW (Willenbrink, 1982) as a poleward undercurrent of the Canary Current but this cannot be traced with salinity further north than $32^{\circ} \mathrm{N}$. The salinity minimum at $32^{\circ} \mathrm{N}$ was higher than 35.55 except for st. 63 . Just at this station, there is a salinity maximum of 36.383 at $1283 \mathrm{~m}$, corresponding to the core of the Meddy "Jani”. Outside this Meddy, the salinity maximum generally decreases towards south and west. The Meddy is also discerned by its temperature maximum at $1200 \mathrm{~m}$ within a rather steady vertical gradient. Below MW a continuous decrease of salinity and temperature denotes the presence of LSW and NADW. In the northern section, the salinity and temperature are slightly higher than at the southern section, probably related to the influence of MW (Arhan and King, 1995).

To remove the saline effect over $A_{T}$ and $C_{T}$, normalised $A_{T}\left(N_{T}=A_{T} / S \cdot 35\right)$ and normalised $\mathrm{C}_{\mathrm{T}}\left(\mathrm{NC}_{\mathrm{T}}=\mathrm{C}_{\mathrm{T}} / \mathrm{S} \cdot 35\right)$ are shown. A steeper vertical gradient of $\mathrm{NA}_{\mathrm{T}}$ was observed below the main thermocline in all sections and slightly higher values were found in the southern section. The silicate distribution showed also a pattern similar to that of $\mathrm{NA}_{\mathrm{T}}$ (correlation between both variables is $\mathrm{r}^{2}=0.96$ with $\mathrm{n}=403$ and a $\mathrm{NA}_{\mathrm{T}} / \mathrm{SiO}_{2}$ ratio of $1.88 \pm 0.02$ ). Furthermore we can observe a minimum of silicate and $\mathrm{NA}_{\mathrm{T}}$ at the salinity maximum of MW. Between Lanzarote Island and the African coast, the maximum of $\mathrm{SiO}_{2}$ of $16.6 \mu \mathrm{mol} \cdot \mathrm{kg}^{-1}$ close to the bottom $(1200 \mathrm{~m})$ is associated opal redissolution. The maximum influence of AAIW is recorded at $800 \mathrm{~m}$ by the minimum of salinity and $\mathrm{pH}_{\mathrm{sws}}$.

On the other hand, $\mathrm{NC}_{\mathrm{T}}, \mathrm{NO}_{3}$ and $\mathrm{AOU}$ distributions, affected by the regeneration of organic matter, show similar patterns and present high correlation $\left(r^{2}>0.77\right)$ among them (Fig. 2). $\mathrm{NC}_{\mathrm{T}}$ distribution is also affected by redissolution of $\mathrm{CaCO}_{3}$. Phosphate distribution (not shown) is very similar to that of nitrate, with a high correlation between them $\left(r^{2}=0.98\right.$, $\mathrm{N}: \mathrm{P}=15.4 \pm 0.1 \mathrm{n}=472$ ). The domain of ENACW is characterised by a gradient of $\mathrm{NC}_{\mathrm{T}}, \mathrm{NO}_{3}$ and AOU with values increasing from surface down to $800 \mathrm{~m}$. The degree of ventilation of this water mass as deducted from the AOU distribution, does not show significant differences in the upper 
thermocline. At deeper levels, the signal of the Meddy is clearly discerned by its moderate AOU values, a product of its low oxygen content and its warm temperature. However, the low nitrate levels and high $\mathrm{pH}_{\mathrm{sws}}$ of the Meddy suggest a relative low age. In the southeast, the influence of AAIW is manifested by its low AOU and $\mathrm{pH}_{\text {sws }}$ values $\left(149 \mu \mathrm{mol} \cdot \mathrm{kg}^{-1}\right.$ and 7.636 respectively), and by an absolute nitrate maximum of $27 \mu \mathrm{mol} \cdot \mathrm{kg}^{-1}$ at stn. 35, at $799 \mathrm{~m}$ depth. Below the layer of MW core and the poleward intrusion of AAIW, there is a relatively homogenous layer of nutrients, $\mathrm{pH}_{\text {sws }}$ and $\mathrm{AOU}$ in relation to the layer immediately above. Below, the influence of LSW was only apparent in the north-western part of the box by the AOU minimum $(\mathrm{AOU}<80$ $\left.\mu \mathrm{mol} \cdot \mathrm{kg}^{-1}\right)$ around $1800 \mathrm{~m}$. Finally, deep waters presented high nutrient values $\left(>21 \mu \mathrm{mol} \cdot \mathrm{kg}^{-1}\right)$, and consequently low $\mathrm{AOU}$ and $\mathrm{pH}_{\mathrm{sws}}$ being more pronounced in the southern section than in the northern one.

\section{Mixing Model}

Following the water masses description given above, we define a set of end-members in order to describe the thermohaline variability due to mixing. It is not necessary to assume either isopycnal or diapycnal mixing. Fig. 3 shows a $\theta$-S diagram with the whole set of samples. The high correlation between $\theta$ and $\mathrm{S}$ below $2.50^{\circ} \mathrm{C}$ yielded a linear relationship for NADW of $\theta=11.1_{ \pm 0.2} \cdot S-385.0_{ \pm 0.2}$ with $r^{2}=0.987$, which is similar to earlier observations (Saunders, 1986; Castro et al. 1998; Paillet and Arhan, 1998). So we chose the lowest $\theta$-S pair for the lower endmember of NADW (NADWl). For the upper limit of NADW (NADWu) we have used the same Ө-S point as suggested by Castro et al. (1998) based on the lower limit of MW influence (Harvey, 1982). This $\theta$-S point is very similar to the end-member used by Stoll et al. (1996) to define the Lower Deep Water in the Iceland basin. Regarding the LSW end-member we have adopted the $\theta$-S properties reported by Talley and McCartney (1982) when the LSW crosses the Mid Atlantic Ridge $\left(3.40^{\circ} \mathrm{C}\right.$ and 34.89). We have selected the thermohaline characteristics of MW $\left(11.74^{\circ} \mathrm{C}\right.$ and 36.5$)$ from Wüst and Defant (1936) near Cape St. Vicente (Rhein and Hinrichsen, 1993). Finally, taking into account that ENACW is composed of two different sets 
of mode waters, the typical line defining ENACW (Sverdrup et al., 1942) has been divided into two segments corresponding to these two varieties; subtropical (ENACWt) and subpolar (ENACWp) mode waters (Harvey, 1982; McCartney and Talley, 1982; Ríos et al. 1992). We keep the same acronyms for the shallow and deep end-members of ENACWt and ENACWp, respectively. The area studied during the Meteor 37/2 cruise is close to the region of formation of the Madeira Mode Water (Siedler et al., 1987). According to these authors, this water mass corresponds to the mode water with the highest volumetric census in the Eastern Subtropical Atlantic, and consequently we have considered their $\theta-S$ properties for the ENACWt endmember $\left(18.5^{\circ} \mathrm{C}, 36.675\right)$. On the other hand, we have chosen $12.2^{\circ} \mathrm{C}$ and 35.66 as the lower limit of ENACWt and, consequently, the upper limit of ENACWp following Harvey (1982). Thus, the latter $\theta$-S pair, represented by H (Fig. 3), has been selected to separate ENACWt from ENACWp. Following the earlier paper of Castro et al. (1998), the ENACWp end-member has a temperature of $8.56^{\circ} \mathrm{C}$ and salinity of 35.23 , so establishing the triangle of mixing between ENACWp (H-ENACWp) and MW without LSW contribution (Fig. 3), since the contribution of LSW occurs below the salinity maximum of MW (below $1100 \mathrm{~m}$. depth). The mixing below the core of MW is quantified from the triangle ENACWp, MW and LSW. Thus the ENACWp-MW line joins the MW maximum in each profile.

Between the Lanzarote island and the African coast (stns. 27 to 35), the AAIW influence is evident, for salinities lower than 35.4 (Fig2a) as commented before. In order to evaluate the influence of AAIW in this channel, the ENACWp point is replaced by the AA endmember (Fig. 3), whose thermohaline characteristics $\left(6.5^{\circ} \mathrm{C}\right.$ and 34.9$)$ have been defined by Fraga et al. (1985) off Cape Blanc $\left(\sim 20^{\circ} \mathrm{N}\right)$ and are similar to those measured by Tsuchiya et al. (1992) at $20^{\circ} \mathrm{N}$ and $20^{\circ} \mathrm{W}$. The term AAIW must only be used for the water mass of $4^{\circ} \mathrm{C}$ and salinity 34.2 formed in the Subantarctic front at about $45^{\circ} \mathrm{S}$ (Reid, 1994).

Taking into account that the distributions of thermohaline and chemical parameters is strongly influenced by the spreading of MW and the influence of AAIW in the studied area, we employ this triangular mixing approach to estimate the contribution from each source. The 
triangles are established in a way, that one side of the triangle corresponds to a layer of mixing between maximum and minimum of salinity and, consequently, samples above this layer do not mix with samples below it and belong to another triangle. The samples from sea surface to the first upper salinity maximum, about $100 \mathrm{~m}$, are excluded from the analysis because their thermohaline properties are altered by atmospheric conditions and do not follow a conservative behaviour. The ENACWp and NADW water mass was modelled by the segment H-ENACWt and NADWl-NADWu, respectively.

The contribution of the water masses considered $\left(\mathrm{M}_{\mathrm{k}, \mathrm{i}}\right)$ to a given sample "i" can be calculated solving the following determined system of three linear equations

$$
\begin{aligned}
1 & =\Sigma \mathbf{M}_{\mathbf{k}, \mathbf{i}} \\
\mathbf{S}_{\mathbf{i}} & =\Sigma \mathbf{M}_{\mathbf{k}, \mathbf{i}} \cdot \mathbf{S}_{\mathbf{k}} \\
\theta_{\mathbf{i}} & =\Sigma \mathbf{M}_{\mathbf{k}, \mathbf{i}} \cdot \theta_{\mathbf{k}}
\end{aligned}
$$

where $\mathrm{k}$ is the water mass (ENACWt, H, ENACWp, MW, AA, LSW, NADWu, NADWl) and ' $\mathrm{i}$ ' is the sample number (from 1 to 408 ). $\mathrm{S}_{\mathrm{k}}$ and $\theta_{\mathrm{k}}$ are the thermohaline characteristics of the k-water mass endmember. As each sample is comprised within the limits of an unique triangle or $\theta / S$ segment, $M_{k, i}$ must be set to zero for the other four water masses. Once $M_{k, i}$ has been calculated for the 408 samples, the expected concentration of any chemical variable for the six end-members in the study area $\left(\mathrm{C}_{\mathrm{k}}\right)$ was obtained solving the corresponding 408 equations by a least-squares approach (Castro et al. 1998; Pérez et al., 1998):

$$
\mathbf{C}_{\mathbf{i}}=\Sigma \mathbf{M}_{\mathbf{k}, \mathbf{i}} \cdot \mathbf{C}_{\mathbf{k}}
$$

As any multilineal fitting, this procedure also provides the theoretical values of the variable $\mathrm{C}_{\mathrm{k}}$ and the residual or anomaly for every sample.

\section{Validation by conservative tracers}

In order to support the proposed mixing model, we have applied the equation system (2) to two conservative tracers. Following Broecker (1974), we have used the tracer 'NO' with an 
$\mathrm{R}_{\mathrm{N}}$ of 9.33 (Anderson, 1995; Fraga et al. 1998) to eliminate the effect of remineralization of organic matter (ROM) on the nitrate and oxygen variability. The mixing model explains $98.6 \%$ of 'NO' variability (Table 1). The standard deviation of 'NO' residuals $\left(9 \mu \mathrm{mol} \cdot \mathrm{kg}^{-1}\right)$ is half of the one expected from the combination of the residuals of nitrate and oxygen $\left(1.2 \cdot 9.33+7.2=18.4 \mu \mathrm{mol} \cdot \mathrm{kg}^{-1}\right)$. Ríos et al. (1998) introduced a new combined chemical tracer 'NCO' which improves the conservative behaviour of 'NO'. In nutrient-depleted waters or in damaged phytoplankton cells, the synthesis of organic matter does not always follow the stoichiometric ratio of average phytoplankton composition, due to the synthesis of an excess of carbohydrates (Cullen et al.,1985; Villareal et al, 1999). Ríos et al. (1998) combined the synthesis of carbohydrates and the typical composition of phytoplankton to define:

$' \mathrm{NCO} '=\mathrm{O}_{2}+\mathrm{CO}_{2}+\mathrm{NO}_{3} \cdot \mathrm{R}_{\mathrm{N}} \cdot\left(1-1 / \mathrm{R}_{\mathrm{C}}\right)={ }^{\prime} \mathrm{NO}{ }^{\prime}+\left(\mathrm{CO}_{2}-\mathrm{NO}_{3} \cdot \mathrm{R}_{\mathrm{N}} / \mathrm{R}_{\mathrm{C}}\right)$

The second summand of the last term accounts for the synthesis or mineralization of the carbohydrate excess over the typical organic matter synthesis of phytoplankton (Fraga and Pérez, 1990; Laws, 1991, Ríos et al. 1998). $\mathrm{R}_{\mathrm{N}}$ of 9.33 and $\mathrm{R}_{\mathrm{C}}$ of 1.41 are the stoichiometric ratios of this average synthesis. The mixing model explains $99.1 \%$ of 'NCO' variability which is higher than that of 'NO' (Table 1 and Fig. 4a). The standard deviation of 'NCO' residuals (5.6 $\mu \mathrm{mol} \cdot \mathrm{kg}^{-1}$ ) is three times lower than the one expected from the combination of the residuals of 'NO', nitrate and $\mathrm{CO}_{2}$ (Table 1). The distribution of 'NCO' residuals (Fig. 4b) is very patchy and does not present clear relation with the distribution of 'NCO' or any other biogeochemical variable. So, the high variability of 'NO' and 'NCO' predicted by the mixing model supports the quality of the model.

In contrary to 'NO' or 'NCO', nitrate, oxygen and $\mathrm{C}_{\mathrm{T}}$ in subsurface waters are affected by ROM. Therefore, they do not completely behave as conservative variables. However, we shall apply the model to these variables, assuming a conservative behaviour (Pérez et al., 1993; Castro et al. 1998; Pérez et al. 1998). We should expect a less percentage of explained variance 
for these chemical properties due to ROM. The AOU distributions clearly showed the patterns of the ROM accumulate in the water masses since its formation (Redfield et al. 1963; Broecker 1974). The vertical profiles of AOU (Fig. 2h) along the studied region are quite similar and the model fits a great part of AOU variability. So, part of the $C_{T}, A_{T}$, nitrate and silicate variability caused by ROM is also included in the values of the end-members. The mixing model splits their variability in two parts, one is included in the nutrient concentrations predicted by the model derived end-members and the other part is included in the residuals and mainly related to the ROM in the studied area. This partition depends on the average residence time of the water masses in the study area. As the residuals vary independently from $\theta$ and $\mathrm{S}$, their distributions can be related with the variability of the ROM within the area; this will be commented on the next section.

Output of mixing model: Chemical characterisation of the water masses

In table 1 we show the nutrient end-members obtained after applying the mixing model. The variances explained by the application of the model for the distribution of $\mathrm{C}_{\mathrm{T}}, \mathrm{A}_{\mathrm{T}}$, nitrate and silicate are greater than $96.7 \%$, while the variance explained for oxygen is slightly lower (93\%). This difference in the proportion of not-explained variability is related to the magnitude of the total natural variance of each chemical tracer. The range of variation in the oxygen endmembers is lower than the one of nitrate, if the stoichiometric ratios ( $\Delta \mathrm{P}: \Delta \mathrm{N}: \Delta \mathrm{C}: \Delta \mathrm{O}_{2} \equiv$ 1:16:106:149) of ROM are taken into account (Anderson, 1995; Fraga et al., 1998). The ratios of variance not explained by the model are $\Delta \mathrm{P}: \Delta \mathrm{N}: \Delta \mathrm{C}: \Delta \mathrm{O}_{2} \equiv 1: 14: 79: 83$ (Table 1), being of the same order than the stoichiometric ratios. In addition, the combined variables 'NO' and 'NCO' defined in order to remove the effects of ROM, are much better fitted than $\mathrm{O}_{2}$ and nutrients. Silicate is less affected by redissolution than the other nutrients and presents a slightly better fit. The model defines very well the $A_{T}$ end-members and its natural variability. Errors of both $A_{T}$ end-members and residuals are close to the analytical errors. 
The nutrient end-members summarise the chemical variability of the water masses. The AOU end-members show low values (young waters) only in the upper ocean. The subtropical region is far from the outcropping region of most water masses involved in the sampled area. Deep waters, including LSW, show similar AOU values and rather similar nutrients concentrations and $\mathrm{pH}_{\mathrm{sws}}$. The $\mathrm{AA}$ end-member is the oldest, probably due the influence of AAIW, which takes a long time to travel from its formation area and passes upwelling areas with strong biological activity. Although its nitrate, phosphate and AOU levels are very high, its silicate content is not as high compared to the one observed in the equatorial region (about 30$\left.35 \mu \mathrm{mol} . \mathrm{kg}^{-1}\right)$. When the AAIW cross the North Equatorial Current, it suffers a strong dilution with the waters present north of the subtropical gyre, mainly, ENACW and MW. With similar temperature, the upper limit of the subpolar ENACW $(\mathrm{H})$ and the MW present similar levels of AOU, $\mathrm{pH}_{\mathrm{sws}}$ and nutrients, though they are probably younger than the AA and ENACWp endmembers. The extrapolation from the H-ENACWp segment to AA using temperature as master variable yields to higher oxygen concentrations in a $13 \%$ and a slightly higher nitrate than those values given by the mixing model.

Remineralisation of organic matter and distributions of residuals.

The distribution of residuals (measured minus modelled values) shows a defined, nonrandomised behaviour and a similarity between $\mathrm{C}_{\mathrm{T}}$, oxygen, $\mathrm{pH}_{\mathrm{sws}}$ and nutrients (Fig. 4). Once the variability caused by mixing is removed with the mixing model, the residual variability can be mainly ascribed to either ROM or dissolution of hard parts of biogenic matter. ROM affects mainly oxygen, $\mathrm{pH}_{\mathrm{Sws}}$, nitrate and $\mathrm{C}_{\mathrm{T}}$, and redissolution increases silicate, $\mathrm{C}_{\mathrm{T}}$ and $\mathrm{A}_{\mathrm{T}}$. White areas in Fig. 4c-4h, indicate regions where both processes increase the levels of nitrate, silicate, AOU, $\mathrm{NC}_{\mathrm{T}}, \mathrm{NA}_{\mathrm{T}}$ and decrease $\mathrm{pH}_{\mathrm{Sws}}$, while shaded areas are related to recent advection of seawater (relatively new) into the area. The spatial distribution of white and shaded areas is rather coincident in the whole set of residual maps. Phosphate anomalies (not shown) present a rather similar pattern. The correlation between phosphate and nitrate residuals is $r^{2}=0.49$ with a 
$\mathrm{N}: \mathrm{P}$ ratio of $13.8 \pm 0.7$. The $\mathrm{AOU}$ and nitrate residuals also show a significant correlation $\left(r^{2}=0.41\right)$ with a $R_{N}$ of $6.1 \pm 0.3$ which is somewhat lower than expected from ROM. The AOU and $\mathrm{C}_{\mathrm{T}}$ residuals present a better correlation $\left(\mathrm{r}^{2}=0.48\right)$, with $\mathrm{R}_{\mathrm{C}}$ of $1.1 \pm 0.06$ which is also lower than expected by ROM (Takahashi et al., 1985, Minster and Boulahdid, 1987; Anderson, 1995, Ríos et al., 1998). The small extension of the study area, and the good fit of the model yields low variances of the residuals and therefore, no high correlation between them should be expected. The analytical error is also included in the residual distribution thus reducing the correlation and estimated ratios. The best correlation between residuals was obtained between $\mathrm{pH}_{\mathrm{sws}}$ and $\mathrm{AOU}\left(\mathrm{r}^{2}=0.66\right)$ with a ratio $\Delta \mathrm{AOU}: \Delta \mathrm{pH}_{\mathrm{sws}}$ of $729 \pm 26$. If the oxygen data are included to calculate the $\mathrm{pH}_{\mathrm{sws}}$ values, the correlation between real and modelled data rise from $r^{2}=0.989$ to 0.995 decreasing the standard deviation of residuals from 0.0099 to 0.0061 , slightly higher than the expected analytical error (0.004).

Spencer (1975) reported ratios of $\Delta \mathrm{Si} / \Delta \mathrm{N}$ between 0.5 to 1.2 , which implies a ratio $\mathrm{R}_{\mathrm{Si}}$ $\left(=-\Delta \mathrm{O}_{2} / \Delta \mathrm{Si}\right.$ ) from 9 to 20 . We found here low and significant covariation between silicate and oxygen residuals $\left(r^{2}=0.14, n=403\right)$ with $R_{S i}$ of $10 \pm 3$, similar to the one calculate previously in the Eastern North Atlantic (Pérez et al., 1993; Castro et al., 1998, Pérez et al., 1998). However, in deep waters (depth $>1500$ ) the correlation is higher $\left(r^{2}=0.49, n=150\right)$ with $R_{S i}$ of $2.7 \pm 0.1$, in agreement with that estimated by Castro et al. (1998) in deep waters between $39^{\circ}$ and $48^{\circ} \mathrm{N}$.

The similarity between the ratios calculated here and those reported in the literature supports the idea that the residuals of the mixing model are mainly due to ROM or redissolution of hard structures, which are strongly dependent on the residence time of the water masses in the area. Taking into account that the geographical distributions of the anomalies (Fig. 4) of the different variables show a very similar behaviour, the results of nutrients and oxygen anomaly can be described in terms of ageing or ventilation. Generally, the northern section shows clearly lower nutrients, $\mathrm{C}_{\mathrm{T}}, \mathrm{A}_{\mathrm{T}}$ and $\mathrm{AOU}$ (higher $\mathrm{pH}_{\mathrm{sws}}$ ) than the southern one with the $18^{\circ} \mathrm{W}$ meridional section as a transition between the two zonal sections. The north-north-east to southsouth-west advection of water masses in practically all levels (Reid, 1994; Paillet and Mercier, 
1997) introduces relatively younger water from the north and the effect of the high productivity upwelling area close to the African coast could contribute to the increase of nutrients in the southern section. The poleward intrusion of waters with AAIW characteristics between the Lanzarote island and the African coast (stns. 33 and 35) creates a maximum of ROM (negative $\mathrm{pH}_{\text {sws }}$ and positive $\mathrm{C}_{\mathrm{T}}$, AOU and nitrate anomalies) between $500 \mathrm{~m}$ and the salinity minimum at 800m depth. Below, there exists a bottom layer with relatively low ROM. Also, the deep Meddy seems to introduce a mesoscale structure in the ROM pattern.

Comparison with data outside the study area.

A similar mixing analysis has been made in other areas of the Eastern North Atlantic Basin. Pérez et al. (1993), used data from several cruises between 40 to $47^{\circ} \mathrm{N}$ and 8 to $11^{\circ} \mathrm{W}$ and provided the chemical characterisation of the water masses close to the Iberian Peninsula from 100 to $2500 \mathrm{~m}$ depth and made a comparison with data from other areas of the North Atlantic using chemical conservative tracers. Castro et al. (1998) used data from the Vivaldi cruise (39$48^{\circ} \mathrm{N}$ and 9 to $24^{\circ} \mathrm{W}$ ) to resolve the chemical characterisation of the same water masses as in the present study and validate their results using the data from Transient Tracer Ocean (TTO). Data from two sections along $22^{\circ} \mathrm{W}$ and $41^{\circ} \mathrm{N}$ resulting from the ANA cruise (Ríos et al. 1992) allowed to fit the chemical variability of the water masses in the upper 1100m (Pérez et al.,1998) including the influence of AAIW and resulted in a good comparability with data from TTO and from the area of the Mauritania upwelling (TTO, 1981; Manríquez and Fraga, 1978). Taking into account data from several cruises in the European Basin from 31 to $53^{\circ} \mathrm{N}$, van Aken (2000b) has recently made the chemical characterisation of water masses using isopycnal analysis. The chemical characterisation from the latter work is included in the Table 2, together with the results obtained here.

\section{a) Central Waters}

The ENACW is composed from several source water (subtropical and subpolar) and is affected by the northward spreading of AAIW. In addition, the salinity maximum of ENACW 
varies latitudinally, thus introducing different ENACWt end-members. To study the agreement between different data bases, Fig. 5 shows the main covariation between conservative and nonconservative variables. The spatial variability in the ventilation of ENACW results in different values for the non-conservative chemical tracer for a given end-member. However, this behaviour is constrained by the ratios of variability of the ROM. The nitrate and phosphate values of ENACW end-members present a very high correlation $\left(\mathrm{r}^{2}=0.995, \mathrm{NO}_{3}=15.15 \cdot \mathrm{PO}_{4}\right.$ +1.25). Also the $\mathrm{C}_{\mathrm{T}} / \mathrm{A}_{\mathrm{T}}$ ratio (=Xca), which has a very strong relation with $\mathrm{pH}_{\mathrm{Sws}}$, shows a high linear correlation (Fig. 5a). Although the recycling of silicate and nitrate follows different pathways, the values of the end-members show a very high non-linear correlation, which reveals increase of $\mathrm{SiO}_{2}: \mathrm{NO}_{3}$ ratio with depth due to the increase of redissolution of opal skeletons and decrease of ROM. Also, the AOU and nitrate end-member values showed high correlation $\left(r^{2}=0.94\right)$, resulting in a very linear behaviour of the conservative tracer 'NO' (Fig. 5b) and 'PO'.

A simple and conservative chemical variable, $\mathrm{C}_{\mathrm{T}}{ }^{*}$, could be defined from $\mathrm{C}_{\mathrm{T}}$ in similar way as pre-formed nitrate (Broecker, 1974), if the $\mathrm{C}_{\mathrm{T}}$ values are corrected for ROM using AOU and $\mathrm{R}_{\mathrm{C}}=1.41$,

$$
\mathrm{C}_{\mathrm{T}} *=\mathrm{NC}_{\mathrm{T}}-\mathrm{AOU} / \mathrm{R}_{\mathrm{C}}
$$

The $\mathrm{C}_{\mathrm{T}} *$ values for the end-members of ENACW show a very good correlation with $\theta$ and are also in agreement for the different data bases. However, the $\mathrm{C}_{\mathrm{T}}$ value for the AA end-member observed during the ANA cruise gave lower values for $\mathrm{Xca}$ and $\mathrm{C}_{\mathrm{T}}{ }^{*}$ compared to those observed here. The ANA cruise went south of $20^{\circ} \mathrm{N}$, where the influence of AAIW is higher. Given the anthropogenic influence on $\mathrm{C}_{\mathrm{T}}, \mathrm{Xca}$ and $\mathrm{C}_{\mathrm{T}}{ }^{*}$, the $\mathrm{C}_{\mathrm{T}}$ of $\mathrm{AA}$ is lower by about 10 to 20 $\mu$ mol.kg-1 compared to ENACW (Pérez et al. 1998).

b) How is the actual advection of AAIW along the eastern boundary?

Assuming a conservative behaviour of silicate, Tsuchiya (1989) extended the intrusion of AAIW beyond $45^{\circ} \mathrm{N}$. The physical and chemical characteristics of the AAIW end-member 
used by van Aken (2000b) are very similar to those of the ENACWp end-member proposed in this work and previous works for the European basin (Willenbrink, 1982; Harvey, 1982; McCartney and Talley; 1982; Arhan et al. 1994; Castro et al. 1998). van Aken (2000b) considered that the salinity minimum of ENACWp indicates the presence of AAIW. However, several authors (Harvey, 1982; McCartney and Talley; 1982; Arhan et al. 1994) described the formation of subpolar mode water in the European Basin with salinities from 35.40 to 35.66 and its southward spreading from $43-48^{\circ} \mathrm{N}$ to the Subtropical gyre. Käse et al. (1986) described the spreading of this subpolar mode water throughout in the Canary basin. Paillet and Mercier (1997) traced the southward spreading of ENACW $\mathrm{P}_{\mathrm{P}}$ from 44 to $25^{\circ} \mathrm{N}$ by a minimum in potential vorticity. In the upwelling area, from the depth of ENACW to the bottom, Reid (1994) described a maximum of $\mathrm{AOU}$ at $24^{\circ} \mathrm{N}$ and its northward spreading making up a steep northsouth gradient of AOU and nutrients north of the Canary Islands, similar to the one described here. The most striking feature showed by Reid (1994) at $\gamma_{1000}=32$ is a strong silicate increase along the NW coast of Africa, suggesting the strong effect of the productive upwelling water on the biogeochemical behaviour of deep waters. Enhanced productivity and consequently ROM in the coastal upwelling off North Africa both play a significant part in creating the tropical oxygen minimum in the eastern North Atlantic (Kawase and Sarmiento, 1986). The oxygen minimum must be also physically isolated from direct ventilation with the atmosphere (Doney and Bullister, 1992). So, these combined biogeochemical processes and its north-south gradient could tend to an incorrect description of the presence of AAIW at latitudes north of $24^{\circ} \mathrm{N}$, if it is traced on basis on nutrient maxima.

The use of conservative chemical tracers can give information about the real water masses contribution in the layer between 500 to $1000 \mathrm{~m}$. The 'NO' and $\mathrm{C}_{\mathrm{T}}{ }^{*}$ values of AAIW $\left(\theta=3.9^{\circ} \mathrm{C}, \mathrm{S}=34.2\right)$ in its formation area at the SAF (Sub Antarctic Front) are 518 and 2165 $\mu \mathrm{mol} \cdot \mathrm{kg}^{-1}$ (Le Groupe CITHER-3, 1998). When reaching $10^{\circ} \mathrm{S}$, AAIW has partially mixed with South Atlantic Central Water and NADWu thus increasing salinity and temperature (34.5 and 4.67 ${ }^{\circ} \mathrm{C}$ ) and decreasing 'NO' and $\mathrm{C}_{\mathrm{T}}{ }^{*}$ values (472 and $2135 \mu \mathrm{mol} . \mathrm{kg}^{-1}$ ). At this latitude the 
nutrients reach maximum values (Reid, 1994) due to ROM. Nitrate and silicate concentrations rise to 35.6 and $32.9 \mu \mathrm{mol} \cdot \mathrm{kg}^{-1}$, respectively (Le Groupe CITHER-3 , 1998). At $10^{\circ} \mathrm{N}$, the minimum of salinity, that is a typical indicator for the spreading of AAIW, is higher than 34.9, and its 'NO' and $\mathrm{C}_{\mathrm{T}}{ }^{*}$ values decrease to 459 and $2095 \mu \mathrm{mol} \cdot \mathrm{kg}^{-1}$, respectively. Data from the ATLOR cruise, at $20^{\circ} \mathrm{N}$ close to the African coast, yielded 'NO' values of $420 \mu \mathrm{mol} \cdot \mathrm{kg}^{-1}$ for AAIW with $6.5^{\circ} \mathrm{C}$ (Manríquez and Fraga, 1978). The chemical characterisation of the endmember AA by using data from ANA cruise $\left(24-28^{\circ} \mathrm{N}\right.$ and $\left.22^{\circ} \mathrm{W}\right)$ yielded similar results for 'NO' $\left(429 \mu \mathrm{mol} . \mathrm{kg}^{-1}\right)$ and $\mathrm{C}_{\mathrm{T}}{ }^{*}\left(2088 \mu \mathrm{mol} . \mathrm{kg}^{-1}\right)$. The presence of AAIW decreases, from $100 \%$ in the SAF, to $75 \%$ at $10^{\circ} \mathrm{S}$, to $64 \%$ at $10^{\circ} \mathrm{N}$ and to $45 \%$ at $24^{\circ} \mathrm{N}$, if linear mixing is assumed with a northern component of thermohaline $\left(9.4^{\circ} \mathrm{C}\right.$ and salinity of 35.3$)$ and chemical (371 and $2089 \mu \mathrm{mol} . \mathrm{kg}^{-1}$ for 'NO' and $\mathrm{C}_{\mathrm{T}}{ }^{*}$, respectively) characteristics similar to the subpolar mode water described by Pérez et al. (1993) and van Aken (2000b) north of $40^{\circ} \mathrm{N}$. The 'NO' of the AA end-member is $396 \mu$ mol. $\mathrm{kg}^{-1}$ with 17\% of pure AAIW and 83\% of ENACWp end-member. During the MET37/2 cruise the sample (St.35, $800 \mathrm{~m}$ ) with the salinity minimum caused by the influence of AAIW was about 35.3 (resolved by the mixing model as $69 \%$ of AA and $29 \%$ of MW). So the maximum percentage of pure AAIW was about $11 \%$ in the poleward undercurrent between Lanzarote Island and the African Coast. From thermohaline data, several authors had previously reported (Willenbrink, 1982; Käse et al., 1986; Reid, 1994), that AAIW is quickly diluted with ENACWp north of $20^{\circ} \mathrm{N}$. So, the increase of nutrients and AOU along the African Coast is due to the remineralization processes linked to the upwelling system (Kawase and Sarmiento, 1986; Reid, 1994; Doney and Bullister, 1992). In addition, the chemical characterisation proposed by van Aken (2000b) for AAIW corresponds closely to the one for ENACWp associated with a salinity minimum located above the MW in the European Basin. (Pérez et al., 1993; Pérez et al., 1998, Castro et al. 1998). In the Canary Basin at 34N, Käse et al. (1986) also ascribed the salinity minimum and $\mathrm{O}_{2}$ maximum above MW to ENACWp.

Östlung and Rooth (1990) noted a decrease with time of the northward spreading of AAIW between $20^{\circ}$ and $30^{\circ} \mathrm{N}$ and the southward penetration of LSW between $40^{\circ}$ and $30^{\circ} \mathrm{N}$ when they compared the radiocarbon distribution from GEOSECS and TTO data. Recently 
Lavin et al. (1998) have calculated the meridional transport and heat flux using three set of hydrographic data from October 1957, August 1981 and July 1992 along 24.5N. Their results show a progressive decrease of northward transport of AAIW from 1957 to 1992. The transport of water with temperatures between 6 and $9^{\circ} \mathrm{C}$ was $3.2 \mathrm{~Sv}$ in 1957, $2.1 \mathrm{~Sv}$ in 1981 and only 0.6 Sv in 1992, even showing a reversed evolution of transport at the $7^{\circ} \mathrm{C}$ level. These authors showed also a parallel decrease of southward transport of LSW along $24.5^{\circ} \mathrm{N}$. All these independent calculations and measurements agree towards a progressive decrease of the northward spreading AAIW during the last decades and may explain the contradiction in the physical and chemical characterisation of AAIW as observed by Tchusiya (1989) using GEOSECS data, and the other recent descriptions (Willenbrink,1982; Käse et al., 1986; Pérez et al., 1993; Pérez et al., 1998, Castro et al. 1998).

\section{c) Deep waters}

The agreement among cruises for the chemical characterisation of MW is fairly good, especially using conservative tracers as 'NO', 'PO' and $\mathrm{C}_{\mathrm{T}}{ }^{*}$. However, the $\mathrm{C}_{\mathrm{T}}{ }^{*}$ value obtained from MET37/2 is rather high, about $0.6 \%$, relative to the other three cruises. A part of this difference could be due to the anthropogenic $\mathrm{CO}_{2}$ input. $\mathrm{AOU}$ and nutrient values of the MW end-members suggest a higher ventilation of MW during the MET37/2 than during the IBERIA and ANA cruises. On the other hand, MW in the VIVALDI cruise showed lower ventilation with high AOU and nutrients compare to the other cruises. The biogeochemical relations are quite consistent. Silicate concentrations in the MW end-members show lower values when sampled near the Gibraltar Strait (van Aken, 2000b) and/or within a strong Meddy (MET37/2). The $\mathrm{A}_{\mathrm{T}}$ values for MW are also coherent $\left(2413 \pm 3 \mu \mathrm{mol} \cdot \mathrm{kg}^{-1}\right)$.

At $25^{\circ} \mathrm{N}$, Doney and Bullister (1992) had dated the age of a Meddy (about 12 to 20 years) during the Oceanus 202 cruise using CFC analysis. These authors also found that the CFC values are lower in the salinity maximum of MW and higher in the salinity minimum above it. From $5^{\circ}$ to $20^{\circ} \mathrm{N}$, Doney and Bullister (1992) reported CFC concentrations in the 
AAIW $(\mathrm{S}<35)$ at or below the blank levels. So, the seawater above MW must have been recently ventilated and therefore is ENACWp and not AAIW.

For LSW, we found a similar coherence in the chemical characterisation with a ventilation pattern just opposite to the previous described for MW. The conservative tracers 'NO', 'PO' and $\mathrm{C}_{\mathrm{T}}{ }^{*}$ show good agreement. Probably, the slightly high 'NO' value calculated for MET37/2 can be ascribed to a higher influence of Southern Atlantic waters. The AOU and nutrients are high in the MET37/2 area due to a lower ventilation of LSW in this region compared to more northern areas (VIVALDI and Iceland Basin). Only a small amount of LSW arrives at the African coast after a long way in a cyclonic eddy $\left(33^{\circ}-43^{\circ} \mathrm{N}\right)$ and also affected by lateral mixing with MW (Reid, 1994). At the depth level of LSW (1800m), MW spreads southwards to the Canary Islands, generating a north-south gradient of AOU and nutrients. In the Canary Basin, Käse et al. (1986) described a MW tongue separating ENACWp and LSW (NW) from AAIW (SE).

The chemical characterisation of both NADW end-members is fairly good. 'NO', 'PO' and $\mathrm{C}_{\mathrm{T}} *$ obtained from the MET37/2 and the IBERIA cruises are very similar, this is also true for AOU and nutrients. The characterisation derived from the VIVALDI data set is very similar to that given by van Aken (2000a) and Stoll et al. (1996) using data from a cruise in the Iceland Basin. However, between both pairs of data sets there are small differences. The AOU and nutrients of the NADWu sampled in the MET37/2 cruise are higher than the levels reported for the area north of $42^{\circ} \mathrm{N}$. Reid (1994) showed a pronounced change of nutrients between the Canary Islands and the Gibraltar Strait, related to the downward intrusion of MW. This spatial variability in NADW practically disappears at the NADWl level. Its chemical characterisation is in agreement for all the variables and for all the cruises, except for the low (by 5\%) silicate values measured during MET37/2. A deep silica tongue along $24^{\circ} \mathrm{N}$, with a maximum close to the African coast, and a steep northward decreasing gradient introduces variability in the silicate distribution between the levels of the $2^{\circ}$ to $3^{\circ} \mathrm{C}$ isotherms in the Canary Basin (Speer, 1993; Reid, 1994). 
Normalised alkalinity shows a very close relation to silicate (Ríos et al., 1995). There is a good correlation between $\mathrm{NA}_{\mathrm{T}}$ and silicate values for the end-members (shown in table 2) gives a high correlation $\left(\mathrm{NA}_{\mathrm{T}}=2289_{ \pm 2}+1.5_{ \pm 0.1} \cdot \mathrm{SiO}_{2}, \mathrm{r}^{2}=0.91, \mathrm{n}=24\right)$ with an average error of 6 $\mu$ mol.kg ${ }^{-1}$. The similar time-scale for the dissolution of hard biogenic structures (opal and $\mathrm{CaCO}_{3}$ ) probably leads to this good correlation (Broecker and Peng, 1982).

\section{CONCLUSIONS}

Application of our simple mixing model for the water masses found in Subtropical Eastern North Atlantic in January 1997 can explain more than 93\% of the chemical variability. The percentage of explained variance is higher for the chemical conservative parameters "NO", "NCO" and $\mathrm{C}_{\mathrm{T}} *$, as the effect of remineralization of organic matter is removed.

The geographical distributions of model residuals clearly discern a region of relatively more ventilated waters, associated with the core of the Azores Current.

From the comparison of the modeled nutrient distribution with data obtained from similar mixing analysis in other regions of the Eastern North Atlantic, we can conclude: (1) the limit of the northward advection of AAIW was localized at $28.5^{\circ} \mathrm{N}$ in the study region being strongly diluted (to <11\% of pure AAIW) by MW and by ENACWp, (2) MW seemed to be more ventilated in the Meteor 37/2 region probably related to the presence of a Meddy, (3) modeled nutrients in the core of LSW were higher than the modeled nutrients for regions further north, as expected if considering the southward advection of this water mass. Furthermore, the upwelling system off Northwest Africa is the main responsible factor for the southward increase of nutrients, $\mathrm{AOU}$ and $\mathrm{NC}_{\mathrm{T}}$.

\section{ACKNOWLEDGEMENTS}


The authors thank the participants in the MET37/2b cruise and the crew of F.S. METEOR for their valuable help. Processing and the modelling work was supported by the MAS3-CT96-60 project of EU. We are very grateful to T. Rellán for the preparation of figures. 


\section{REFERENCES}

Anderson, S.A., 1995. On the hydrogen and oxygen contents of marine phytoplankton. Deep-Sea Res., 42, 1675-1680.

Arhan, M.A., Colin De Verdière, A., Memery, L., 1994. The Eastern Boundary of the Subtropical North Atlantic. J. Phys. Oceanogr. 24(6), 1295-1316.

Arhan, M.A., King, B., 1995. Lateral mixing of the Mediterranean Water in the eastern North Atlantic. J. Mar. Res. 53 865-895.

Broecker, W.S. ,1974. 'NO’, a conservative water-mass tracer. Earth and Planet. Sci. Lett., 23, 100-107.

Broecker, W.S., Peng, T.H., 1982. Tracers in the Sea. Ed. Lamont-Doherty Geological Observatory, New York, 690 pp.

Broecker, W.S., Takahashi, T., 1980. Hydrography of the Central Atlantic-III. The North Atlantic deepwater complex. J. Geophys. Res., 27A, 591-613.

Broenkow, W. W., 1965. The distribution of nutrients in the Costa Rica Dome in the eastern tropical Pacific Ocean. Limnol. Oceanogr., 10: 40-52.

Castro, C.G.,. Pérez, F.F, Holley, S. and Ríos, A.F, 1998. Characterization and modelling of water masses in the Northeast Atlantic. Prog. Oceanogr., 41(3), 249-279. .

Cullen, J.J., Zhu, M., Davis, R.F., Pierson, D.C., 1985. Vertical migration, carbohydrate synthesis and nocturnal nitrate uptake during growth of Heterocapsa niei in a laboratory water column. pag.189-194 in: Toxic dinoflagellates. Anderson, White y Baden Ed.. Elsevier Sci.Publishing Co.

DOE,1994. Handbook of methods for the analysis of the various parameters of the carbon-dioxide system in sea water, A.G. Dickson and C. Goyet (eds.), ORNL/CDIAC-74.

Doney, S. , Bullister, J. L., 1992. A chlorofluorocarbon section in the eastern North Atlantic. Deep-Sea Res., 39(11/12),1857-1883.

Fiúza, A.F.G. , 1984. Hidrologia e dinamica das aguas costeiras de Portugal. Ph. D thesis, Univ. Lisbon. $294 \mathrm{pp}$.

Fraga, F., Pérez, F.F., 1990. Transformaciones entre composición química del fitoplancton, composición elemental y relación de Redfield. Scient. Mar. 54(1): 69-76.

Fraga, F., Barton, E.D., Llinás, O., 1985. The concentration of nutrient salts in "pure" North and South Atlantic Central Waters. Simp. Int. Afl. Afr., Inst. Inv. Pesq., Barcelona, 1: 25-36.

Fraga F., Ríos, A.F. , Pérez, F.F., Figueiras, F.G., 1998. Theoretical limits of oxygen:carbon and oxygen:nitrogen ratios during photosynthesis and mineralisation of organic matter in the sea. Sci. Mar., 62(1-2): 161-168.

Hansen, H.P. , Grasshoff K. , 1983. Automated Chemical Analysis in Methods of Seawater Analysis. K. Grasshoff et al. eds. Verlag Chemie pp 3347-395.

Harvey, J., 1982. $\theta$-S relationships and water masses in the eastern North Atlantic. Deep-Sea Res. 29(8A): 1021-33.

Harvey, J., Arhan, M., 1988. The Water Masses of the Central North Atlantic in 1983-84. J. Phys. Oceanogr., 18, 1855-1875. 
Johnson, K.M., Wills, K.D., Butler, D.B., Johnson, W.K. , Wong ,C.S., 1993. Coulometric total carbon dioxide analysis for marine studies: automation and calibration. Mar. Chem., 44, 167-187.

Käse R.H., Price, J.F., Richardson, P.L., Zenk, W., 1986. A quasi-synoptic survey of the thermocline circulation and water masses distribution within the Canary Basin J. Geophys. Res. 91 (C8) 9739-9748.

Kawase, M., Sarmiento, J.L., 1986. Circulation and Nutrients in Mid-depth Atlantic Waters. J. Geophys. Res., 91(C8), 9749-9770.

Laws E. A. ,1991. Photosynthetic quotients, new production and net community production in the open ocean. Deep-Sea Res. 38(1), 143-167.

Lavin A., Bryden, H.L., Parrilla, G.,1998. Meridional transport and heat flux variations in the subtropical north Atlantic. The Global Atmosphere and Ocean System, 6, 269-293.

Le Groupe CITHER-3 , 1998. Recueil de données. Volume 3: Traceurs Géochimiques. Rapport Interne LPO (98-03): 586 pp.

Le Group Tourbillon , 1983. The Tourbillon experiment: a study of mesoscale eddy in the eastern North Atlantic. Deep-Sea Res., 30, 475-511.

Llinas, O., Rodriguez de Leon, A., Siedler, G., Wefer, G., 1997. ESTOC data report. Inf. Tech. del Inst. Can. C. Mar., Nu. 3, Telde de Gran Canaria.

Mackas, D.L., Denman , K.D., Bennett, A.F. , 1987. Least Squares Multiple Tracer Analysis of Water Mass Composition. J. Geophys. Res., 92(C3), 2907-18.

Manríquez, M., Fraga, F., 1978. Hidrografía de la región de afloramiento del noroeste de África Campaña "ATLOR VII". Res. Exp. Cient. B/O Cornide, 7, 1-32.

McCartney, M. , Talley, T., 1982. The subpolar Mode Water of the North Atlantic Ocean. J. Phys. Oceanogr., 12, 1169-88.

Minas, H.J., Packard, T.T., Minas, M., Coste, B., 1982. An analysis of the production-regeneration system in the coastal upwelling area off N.W. Africa based on oxygen, nitrate and ammonium distributions. J. Mar.Res., 40(3), 615-41.

Minster, J-F., Boulahdid, M., 1987. Redfield ratios along isopycnal surfaces-a complementary study. Deep-Sea Res. 34(12), 1981-2003.

Müller, T.J., Holfort, J., Delahoyde, F., Williams, R., 1995: MKIIIB-CTD: improving its system output. Deep-Sea Res. I, Vol. 42, No. 11/12, 2113-2126.

Östlund, H. G., Rooth, C.G.H., 1990. The North Atlantic Tritium and Radiocarbon Transients 19721983. J. Geophys. Res. 95(C11), 20147-20165.

Paillet, J., Mercier, H., 1997. An inverse model of the eastern North Atlantic general circulation and thermocline ventilation. Deep-Sea Res. I 44(8), 1293-1328.

Paillet, J., Arhan, M., McCartney, M.S., 1998. Spreading of Labrador Sea Water in the eastern North Atlantic. J. Geophys. Res. 103 (C5), 10223-10239.

Pérez, F.F , Fraga, F., 1987.The pH measurements in seawater on NBS scale. Mar. Chem. 21, 315-327.

Pérez, F.F., Mouriño, C., Fraga, F., Ríos, A.F., 1993. Displacement of water masses and remineralization rates off the Iberian Peninsula by nutrient anomalies. J. Mar. Res. 51,1-24. 
Pérez, F.F., Ríos, A.F., Castro, C.G., Fraga, F., 1998. Mixing analysis of nutrients, oxygen and dissolved inorganic carbon in the upper and middle North Atlantic ocean east of the Azores. J. Mar. Syst., 16(3-4), 219-233.

Pollard, R.T., Pu, S., 1985. Structure and Circulation of the Upper Atlantic Ocean Northeast of the Azores. Prog. Oceanog. 14, 443-62.

Redfield, A.C., Ketchum, B.H., Richards, F.A., 1963. The influence of organisms on the composition of sea-water. In The Sea. John Wiley \& Sons, New York, 2, 26-77.

Reid, J.H., 1994. On the total geostrophic circulation of the North Atlantic Ocean: Flow patterns, tracers and transports. Prog. Oceanogr. 33, 1-92.

Rhein, M., Hinrichsen, H.H., 1993. Modification of Mediterranean Water in the Gulf of Cadiz, studied with hydrographic, nutrient and chlorofluoromethane data. Deep-Sea Res. I. 40(2), 267-291.

Ríos, A. F., Fraga, F. , Pérez, F. F., 1989. Estimation of coefficients for the calculation of 'NO’, 'PO’ and 'CO', starting from the elemental composition of natural phytoplankton. Scient. Mar. 53(4), 779784.

Ríos, A.F., Pérez, F.F., Fraga, F., 1992. Water masses in upper and middle North Atlantic Ocean east of the Azores. Deep Sea Res. 39(3/4), 645-658.

Ríos, A. F., Anderson, T., Pérez, F. F., 1995. The carbonic system distribution and fluxes in the NE Atlantic during spring 1991. Prog. Oceanogr. 35(IV), 295-314.

Rios, A.F., Fraga, F. , Figueiras., F.G., Pérez, F.F., 1998.- A modeling approach to the Redfield ratio deviations in the ocean. Sci. Mar. 62(1-2), 169-176.

Saunders, P.M., 1986. The accuracy of measurements of salinity, oxygen, and temperature in the deep ocean. J. Phys. Oceanogr. 16, 189-195.

Siedler G., Kuhl, A., Zenk , W., 1987. The Madeira Mode Water. J. Phys. Oceanogr., 17, 1561-1570.

Speer, K.G., 1993. The deep silica tongue in the North Atlantic. Deep-Sea Res. I. 40(5), 925-936.

Spencer, C. P. , 1975. The micronutrient elements, in Chemical Oceanography, J.P. Riley and G. Skirrow eds., Academic press, London, 1087 pp.

Stoll, M.H.C., van Aken, H.M., de Baar, H.J.W , Kraak, M., 1996. Carbon dioxide of water masses in the northern North Atlantic Ocean. Mar. Chem. 55, 217-232.

Sverdrup H. U., Johnson, M.W., Fleming, R.H., 1942. The oceans: their physics, chemistry, and general biology. Prentice-Hall, Englewood Cliffs, New Jersey, 1087 pp.

Stramma,L., Müller,T.J., 1989. Some observations of the Azores Current and the North Ecuatorial current. J. Geophys. Res. 94(c3), 3181-3186

Takahashi, T., Broecker, W.S., Langer, S., 1985. Redfield Ratio Based on Chemical Data from Isopycnal Surfaces. J. Geophys. Res. 90(C4), 6907-24.

Talley, L.D. , McCartney, M.S., 1982. Distribution and Circulation of Labrador Sea Water. J. Physic. Oceanogr. 12, 1189-1205.

Tomczak, JR., 1981. A multi-parameter extension of temperature/salinity diagram for the analysis of nonisopycnal mixing. Prog. Oceanog. 10, 147-171.

Tomczak, M., Large, D.G.B., 1989. Optimum multiparameter analysis of mixing in the thermocline of the eastern Indian ocean. J. Geophys. Res. 94 (C11), 16141-16149. 
TTO. Transient Tracers in the Oceans North Atlantic Study. Shipboard Physical and Chemical data report 1 April-19 October (1981). Scripps Institution of Oceanography. University of California, San Diego.2.

Tsuchiya, M., 1989. Circulation of the Antarctic Intermediate Water in the North Atlantic Ocean. J. Mar. Res. 47, 747-755.

Tsuchiya, M., Talley, L.D., McCartney, M.S., 1992. An eastern Atlantic section from Iceland southward across the equator. Deep-Sea Res. 39 (11/12), 1885-1917.

UNESCO, 1986. Progress on Oceanographic Tables and Standards 1983-1986. Work and recommendations of the UNESCO/SCOR/ICES/IAPSO Joint Panel. UNESCO Technical Papers in Marine Science, 50.

van Aken, H.M., 2000a. The hydrography of the mid-latitude northeast Atlantic Ocean: The deep water masses. Deep-Sea Res., 47 (5) pp. 757-788.

van Aken, H.M., 2000b. The hydrography of the mid-latitude northeast Atlantic Ocean: The intermediate water masses. Deep-Sea Res , 47 (5) 789-824

Villarreal T.A., Pilskaln, C., Brzezinski, M., Lipschultz, F., Dennett, M., Gardner, G.B., 1999. Upward transport of oceanic nitrate by migrating diatom mats. Nature 397, 423-425.

Willenbrink, E., 1982. Wassermassenanalyse im tropischen und subtropischen Nordostatlantik”. Berichte aus dem Institut für Meereskunde Kiel, 96, 72pp.

WOCE, 1994. WOCE Operations Manual, Vol. 3, Sect. 3.1, Part 3.1.3: WHP Operations and Methods. Rev. 1, Nov. 1994. Woods Hole, Mass. USA.

Wüst, G., Defant, A., 1936. Atlas zur Schichtung und Zirkulation des Atlantischen Ozeans. Schnitte und Karten von Temperatur, Salzgehalt und Dichte. In Wissenschaftliche Ergebnisse der Deutschen Atlantischen Expedition auf dem Forschungs-und Vermessungsschiff “Meteor" 1925-1927, 6 Atlas, 103 plates. 


\section{FIGURE CAPTIONS}

Fig. 1. Location of stations of the MET37/2 cruise( $\bullet$ )

Fig. 2. Distributions along the ship-track (composite of the meridional $\left(18^{\circ} \mathrm{W}\right)$ and the two zonal (29 and $32^{\circ} \mathrm{N}$ ) sections) of salinity (a), potential temperature (b), normalised total alkalinity (c), normalised total inorganic carbon (d), silicate (e), nitrate (f), $\mathrm{pH}_{\mathrm{sws}}$ (g), and AOU (h). The units are in $\mu$ mol. $\mathrm{kg}^{-1}$ except for salinity and $\mathrm{pH}$. Station 49 and 55 are located at the corners on the $18^{\circ} \mathrm{W}$ meridian section (Fig. 1). Shaded area corresponds to the $18^{\circ} \mathrm{W}$ meridional section.

Fig. 3. $\theta$-S diagram of the samples (surface samples excluded) of the MET37/2 cruise with the applied mixing triangles indicated. The black solid symbols represents the samples resolved using the AA end-member. The thermohaline properties of the water types are shown in Table 1.

Fig. 4.Distribution along the ship-track composite of the meridional $\left(18^{\circ} \mathrm{W}\right)$ and the two zonal (29 and $32^{\circ} \mathrm{N}$ ) sections for 'NCO' (a), and anomalies of 'NCO'(b), $\mathrm{C}_{\mathrm{T}}$ (c), AOU (d), $\mathrm{A}_{\mathrm{T}}(\mathrm{e}), \mathrm{pH}_{\mathrm{Sws}}(\mathrm{f})$, silicate (g) and nitrate (h). Except for $\mathrm{pH}$, all units are in $\mu \mathrm{mol} . \mathrm{kg}^{-1}$.

Fig. 5. Chemical characterisation of ENACW (ENACWt: squares, H: triangles, ENACWp: circles, AA: diamond) from different authors and data sets (MET37/2: black, IBERIA: cross inside black symbol, ANA: open symbol, VIVALDI: symbol inside open circle, van Aken (2000b): little cross inside diamond). Upper panel: Covariation between silicate and $\mathrm{Xca}\left(\mathrm{C}_{\mathrm{T}} / \mathrm{A}_{\mathrm{T}}\right)$ versus nitrate. Lower panel: Variation between conservative tracers ' $\mathrm{NO}$ ' and $\mathrm{C}^{*}{ }_{\mathrm{T}}$ versus potential temperature. The curve fits the silicate versus nitrate is second order. Except for Xca and $\theta$, all units are in $\mu$ mol.kg-1 . 

Table 1.- The definition of the eight water types and their chemical characterisation obtained from the mixing model using 408 water samples.

\begin{tabular}{|c|c|c|c|c|c|c|c|c|c|c|c|c|}
\hline & $\mathrm{S}$ & $\theta$ & $\mathrm{O}_{2}$ & $\mathrm{AOU}$ & $\mathrm{NO}_{3}$ & $\mathrm{SiO}_{2}$ & $\mathrm{PO}_{4} \mathrm{H}_{2}$ & $\mathrm{C}_{\mathrm{T}}$ & $\mathrm{A}_{\mathrm{T}}$ & pHSWS & ‘NO’' & ‘NCO’’ \\
\hline ENACWt & 36.675 & $18.50 \|$ & $229 \pm 1$ & -1 & $0.4 \pm 0.2$ & $0.3 \pm 0.2$ & $0.01 \pm 0.01$ & $2090 \pm 1$ & $2397 \pm 0.5$ & $8.004 \pm 0.002$ & $233 \pm 2$ & $2320 \pm 1$ \\
\hline $\mathrm{H}$ & 35.660 & 12.20 & $194 \pm 1$ & 67 & $13.7 \pm 0.2$ & $4.9 \pm 0.2$ & $0.79 \pm 0.01$ & $2148 \pm 1$ & $2336 \pm 0.5$ & $7.808 \pm 0.002$ & $322 \pm 2$ & $2379 \pm 1$ \\
\hline ENACWp & 35.230 & 8.56 & $157 \pm 2$ & 125 & $24.5 \pm 0.3$ & $14.5 \pm 0.4$ & $1.55 \pm 0.02$ & $2189 \pm 2$ & $2321 \pm 1.0$ & $7.685 \pm 0.003$ & $386 \pm 3$ & $2412 \pm 2$ \\
\hline AA & 34.900 & 6.50 & $119 \pm 4$ & 177 & $29.7 \pm 0.6$ & $19.9 \pm 0.7$ & $1.92 \pm 0.04$ & $2218 \pm 3$ & $2312 \pm 1.7$ & $7.582 \pm 0.005$ & $396 \pm 4$ & $2417 \pm 3$ \\
\hline MW & 36.500 & 11.74 & $192 \pm 4$ & 68 & $11.9 \pm 0.6$ & $7.2 \pm 0.7$ & $0.67 \pm 0.04$ & $2205 \pm 3$ & $2414 \pm 1.7$ & $7.831 \pm 0.005$ & $304 \pm 4$ & $2430 \pm 3$ \\
\hline LSW & 34.890 & 3.40 & $237 \pm 2$ & 80 & $22.5 \pm 0.4$ & $19.5 \pm 0.4$ & $1.46 \pm 0.03$ & $2172 \pm 2$ & $2316 \pm 1.1$ & $7.704 \pm 0.005$ & $446 \pm 3$ & $2470 \pm 2$ \\
\hline NADWu & 34.940 & 2.50 & $248 \pm 1$ & 79 & $21.4 \pm 0.2$ & $34.8 \pm 0.3$ & $1.40 \pm 0$ & $2191 \pm 1$ & $2344 \pm 0.7$ & $7.728 \pm 0.002$ & $447 \pm 2$ & $2497 \pm 1$ \\
\hline NADWl & 34.884 & 1.98 & $245 \pm 2$ & 86 & $23.2 \pm 0.3$ & $44.4 \pm 0.3$ & $1.50 \pm 0.02$ & $2204 \pm 2$ & $2353 \pm 0.8$ & $7.722 \pm 0.002$ & $462 \pm 2$ & $2513 \pm 1$ \\
\hline$r^{2}$ & & & 0.93 & & 0.97 & 0.986 & 0.970 & 0.967 & 0.967 & 0.989 & 0.987 & 0.992 \\
\hline STD & & & 7.2 & & 1.2 & 1.4 & 0.086 & 6.7 & 3.3 & 0.010 & 8.3 & 5.6 \\
\hline
\end{tabular}


Table 2.- Calculated chemical properties of the water masses of Eastern North Atlantic from several papers. ANA, IBERIA, VIVALDI, van Aken and ICELAND refers to the papers: Pérez et al. (1998), Pérez et al. (1993), Castro et al. (1998) and van Aken (1999 a and b) and Stoll et al. (1996) respectively.

\section{ENACW}

\begin{tabular}{|l|c|c|c|r|r|r|r|r|r|r|r|r|r|r|}
\hline Reference & $\mathrm{S}$ & \multicolumn{1}{c}{$\theta$} & $\gamma_{500}$ & ${ }^{\prime} \mathrm{NO}$ & ${ }^{\prime} \mathrm{PO}$ & $\mathrm{C}_{\mathrm{T}}{ }^{*}$ & $\mathrm{O}_{2}$ & $\mathrm{AOU}$ & $\mathrm{NO}_{3}$ & $\mathrm{PO}_{4}$ & $\mathrm{C}_{\mathrm{T}}$ & $\mathrm{A}_{\mathrm{T}}$ & $\mathrm{SiO}_{2}$ & Type \\
\hline MET37/2 & 36.672 & 18.50 & 28.607 & 233 & 231 & 1994 & 229 & 0 & 0.4 & 0.01 & 2090 & 2397 & 0.3 & ENACWt \\
\hline IBERIA & 35.815 & 13.71 & 29.094 & 285 & 279 & 2045 & 233 & 20 & 5.6 & 0.32 & 2107 & 2347 & 1.6 & ENACWt \\
\hline ANA & 36.500 & 18.00 & 29.604 & 229 & & 1989 & 195 & 37 & 3.6 & & 2100 & 2380 & 2.0 & ENACWt \\
\hline VIVALDI & 36.120 & 14.86 & 29.073 & 277 & 264 & 2022 & 228 & 19 & 5.2 & 0.25 & 2100 & 2355 & 2.0 & ENACWt \\
\hline MET37/2 & 35.660 & 12.20 & 29.292 & 322 & 307 & 2061 & 194 & 67 & 13.7 & 0.79 & 2148 & 2336 & 4.8 & $\mathrm{H}$ \\
\hline ANA & 35.660 & 12.00 & 29.333 & 317 & & 2057 & 213 & 49 & 11.2 & & 2131 & 2338 & 4.5 & $\mathrm{H}$ \\
\hline VIVALDI & 35.660 & 12.20 & 29.292 & 331 & 316 & 2069 & 254 & 7 & 8.2 & 0.43 & 2113 & 2336 & 2.8 & $\mathrm{H}$ \\
\hline MET37/2. & 35.230 & 8.56 & 29.633 & 386 & 380 & 2085 & 157 & 126 & 24.5 & 1.55 & 2189 & 2321 & 14.6 & ENACWp \\
\hline IBERIA & 35.300 & 9.40 & 29.544 & 371 & 360 & 2084 & 200 & 78 & 18.3 & 1.11 & 2157 & 2325 & 8.1 & ENACWp \\
\hline ANA & 35.230 & 8.58 & 29.629 & 378 & & 2090 & 185 & 98 & 20.7 & & 2174 & 2323 & 11.9 & ENACWp \\
\hline VIVALDI & 35.230 & 8.56 & 29.633 & 373 & 356 & 2091 & 199 & 84 & 18.7 & 1.09 & 2165 & 2315 & 9.7 & ENACWp \\
\hline MET37/2 & 34.900 & 6.50 & 29.696 & 396 & 396 & 2097 & 119 & 178 & 29.7 & 1.92 & 2218 & 2312 & 19.9 & AA \\
\hline ANA & 34.900 & 6.50 & 29.696 & 429 & & 2088 & 116 & 181 & 33.6 & & 2211 & 2306 & 24.1 & AA \\
\hline van Aken $^{b}$ & 35.420 & 9.43 & 29.632 & 360 & 357 & & 170 & 107 & 20.4 & 1.3 & & & 11.5 & AA \\
\hline
\end{tabular}

\section{MW}

\begin{tabular}{|l|c|c|c|r|r|r|r|r|r|r|r|r|r|}
\hline Reference & \multicolumn{1}{c}{$\mathrm{S}$} & $\theta$ & $\gamma_{2000}$ & 'NO' & 'PO' & $\mathrm{C}_{\mathrm{T}}{ }^{*}$ & $\mathrm{O}_{2}$ & $\mathrm{AOU}$ & $\mathrm{NO}_{3}$ & $\mathrm{PO}_{4}$ & $\mathrm{C}_{\mathrm{T}}$ & $\mathrm{A}_{\mathrm{T}}$ & $\mathrm{SiO}_{2}$ \\
\hline MET37/2 & 36.500 & 11.74 & 31.589 & 304 & 289 & 2067 & 193 & 69 & 11.9 & 0.67 & 2205 & 2414 & 7.2 \\
\hline IBERIA & 36.500 & 11.74 & 31.589 & 307 & 294 & 2053 & 166 & 96 & 15.1 & 0.89 & 2209 & 2417 & 10.4 \\
\hline ANA & 36.500 & 11.76 & 31.584 & 308 & & 2053 & 163 & 99 & 15.5 & & 2212 & 2413 & 10.6 \\
\hline VIVALDI & 36.500 & 11.74 & 31.589 & 305 & 295 & 2054 & 145 & 117 & 17.1 & 1.04 & 2225 & 2409 & 11.3 \\
\hline van Aken $^{\mathrm{b}}$ & 36.500 & 12.01 & 31.527 & 305 & 291 & & 177 & 83 & 13.7 & 0.79 & & & 7.6 \\
\hline
\end{tabular}

LSW

\begin{tabular}{|l|c|c|c|c|c|c|c|r|r|r|r|r|r|}
\hline Reference & $\mathrm{S}$ & $\theta$ & $\gamma_{2000}$ & 'NO' & 'PO' & $\mathrm{C}_{\mathrm{T}}{ }^{*}$ & $\mathrm{O}_{2}$ & $\mathrm{AOU}$ & $\mathrm{NO}_{3}$ & $\mathrm{PO}_{4}$ & $\mathrm{C}_{\mathrm{T}}$ & $\mathrm{A}_{\mathrm{T}}$ & $\mathrm{SiO}_{2}$ \\
\hline MET37/2 & 34.890 & 3.400 & 31.907 & 447 & 448 & 2120 & 237 & 83 & 22.5 & 1.47 & 2172 & 2316 & 19.5 \\
\hline IBERIA & 34.890 & 3.400 & 31.907 & 434 & 441 & 2122 & 261 & 59 & 18.5 & 1.25 & 2157 & 2307 & 14.7 \\
\hline VIVALDI & 34.890 & 3.400 & 31.907 & 435 & 423 & 2125 & 270 & 50 & 17.7 & 1.06 & 2154 & 2295 & 10.9 \\
\hline ICELAND $^{3} 34.890$ & 3.400 & 31.907 & 436 & & 2116 & 280 & 40 & 16.7 & & 2141 & & 10.5 \\
\hline van Aken $^{\mathrm{a}}$ & 34.890 & 3.428 & 31.903 & 437 & 440 & & 279 & 40 & 16.9 & 1.12 & & & 10.3 \\
\hline
\end{tabular}

NADW-upper

\begin{tabular}{|l|c|c|c|r|r|r|r|r|r|r|r|r|r|}
\hline Reference & $\mathrm{S}$ & $\theta$ & $\gamma_{2000}$ & 'NO' & 'PO' & $\mathrm{C}_{\mathrm{T}}{ }^{*}$ & $\mathrm{O}_{2}$ & $\mathrm{AOU}$ & $\mathrm{NO}_{3}$ & $\mathrm{PO}_{4}$ & $\mathrm{C}_{\mathrm{T}}$ & $\mathrm{A}_{\mathrm{T}}$ & $\mathrm{SiO}_{2}$ \\
\hline MET37/2 & 34.940 & 2.500 & 32.073 & 448 & 450 & 2138 & 248 & 79 & 21.4 & 1.40 & 2191 & 2344 & 34.8 \\
\hline IBERIA & 34.925 & 2.400 & 32.075 & 445 & 450 & 2136 & 248 & 80 & 21.1 & 1.40 & 2188 & 2337 & 37.4 \\
\hline VIVALDI & 34.940 & 2.500 & 32.073 & 439 & 438 & 2131 & 253 & 74 & 19.9 & 1.28 & 2180 & 2326 & 30.4 \\
\hline ICELAND & 34.940 & 2.500 & 32.073 & 436 & & 2134 & 249 & 82 & 20.4 & & 2183 & 2326 & 35.3 \\
\hline van Aken $^{\mathrm{a}}$ & 34.936 & 2.500 & 32.070 & 440 & 447 & & 249 & 71 & 20.5 & 1.38 & & & 33.6 \\
\hline
\end{tabular}

NADW-lower

\begin{tabular}{|l|c|c|c|r|r|c|c|c|c|c|c|c|c|}
\hline Reference & $\mathrm{S}$ & $\theta$ & $\gamma_{2000}$ & 'NO' & 'PO' & $\mathrm{C}_{\mathrm{T}}{ }^{*}$ & $\mathrm{O}_{2}$ & $\mathrm{AOU}$ & $\mathrm{NO}_{3}$ & $\mathrm{PO}_{4}$ & $\mathrm{C}_{\mathrm{T}}$ & $\mathrm{A}_{\mathrm{T}}$ & $\mathrm{SiO}_{2}$ \\
\hline MET37/2 & 34.884 & 1.980 & 32.099 & 462 & 462 & 2150 & 245 & 86 & 23.2 & 1.51 & 2204 & 2353 & 44.4 \\
\hline VIVALDI & 34.890 & 2.030 & 32.097 & 452 & 469 & 2152 & 238 & 93 & 22.9 & 1.60 & 2211 & 2354 & 46.9 \\
\hline van Aken $^{\mathrm{a}}$ & 34.889 & 1.984 & 32.102 & 452 & 462 & & 245 & 86 & 22.2 & 1.50 & & & 46.3 \\
\hline
\end{tabular}




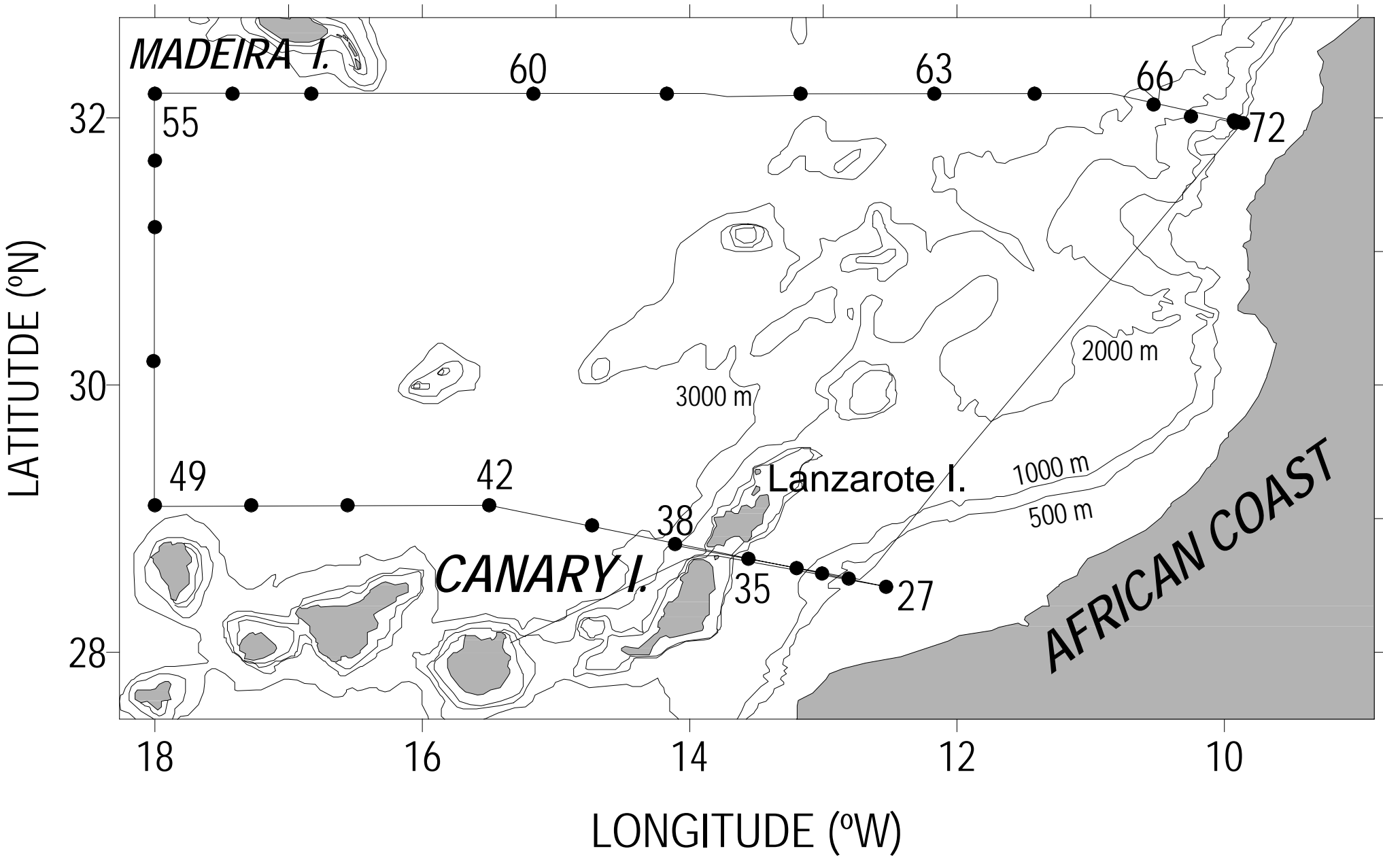




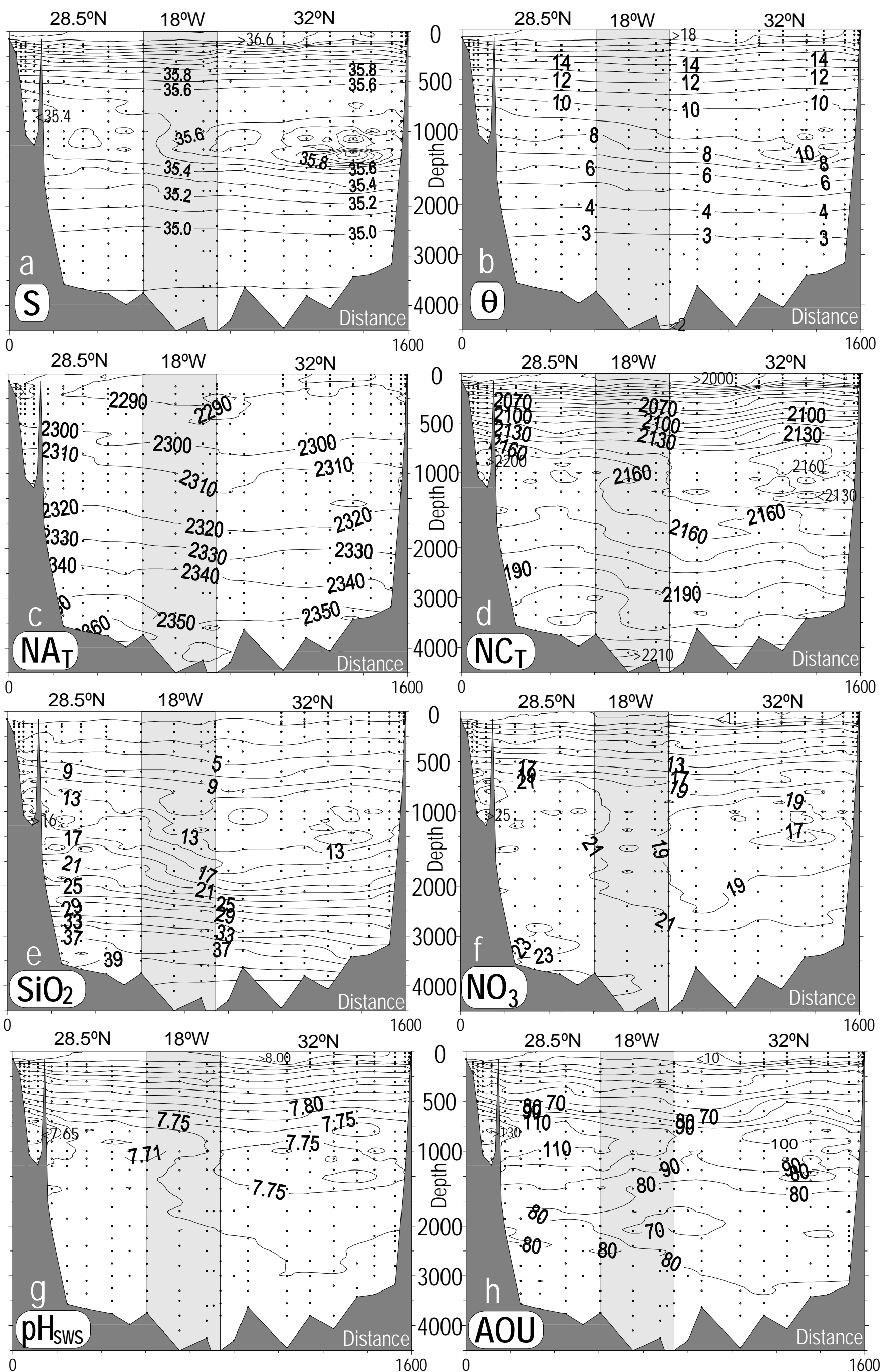




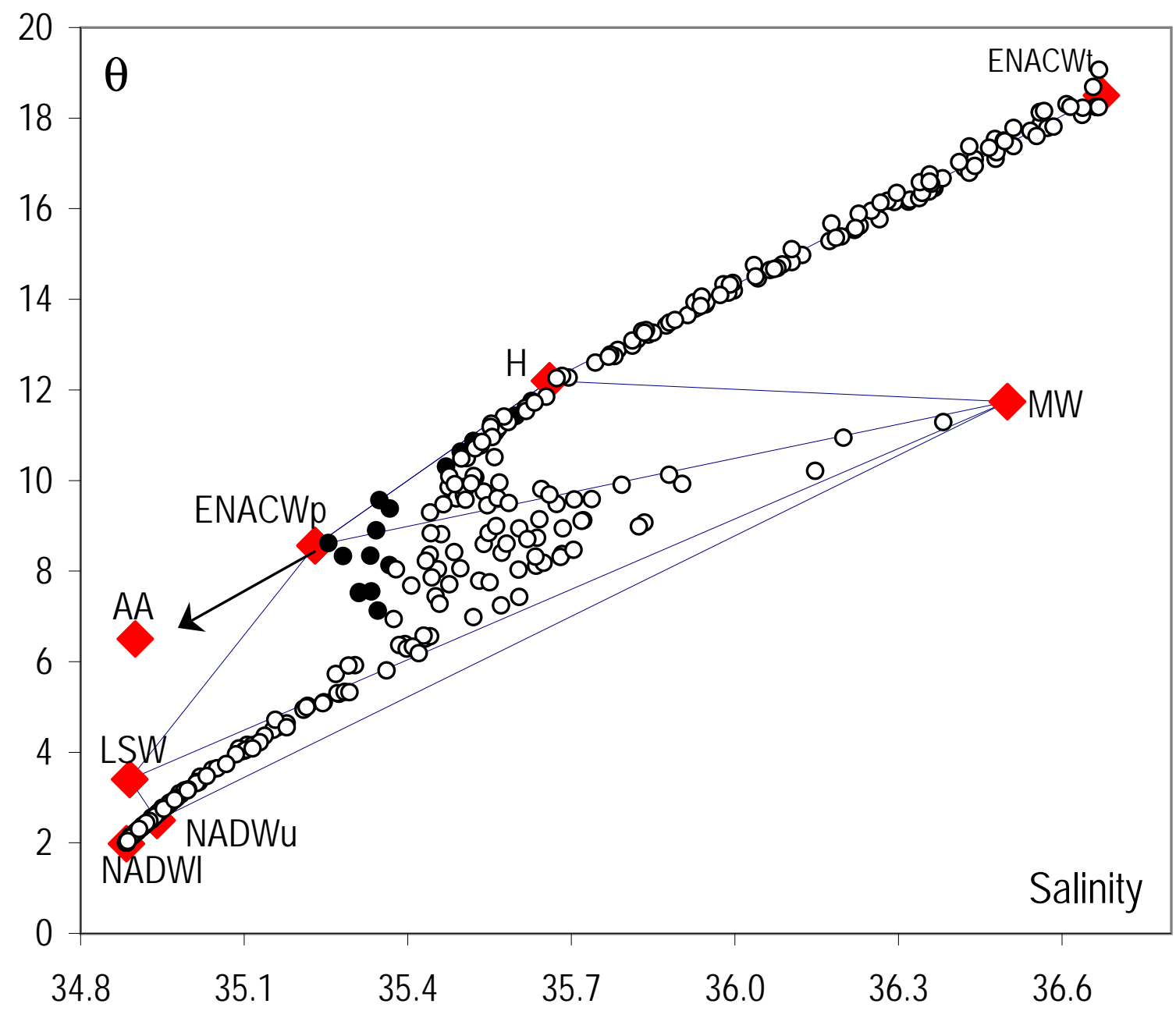



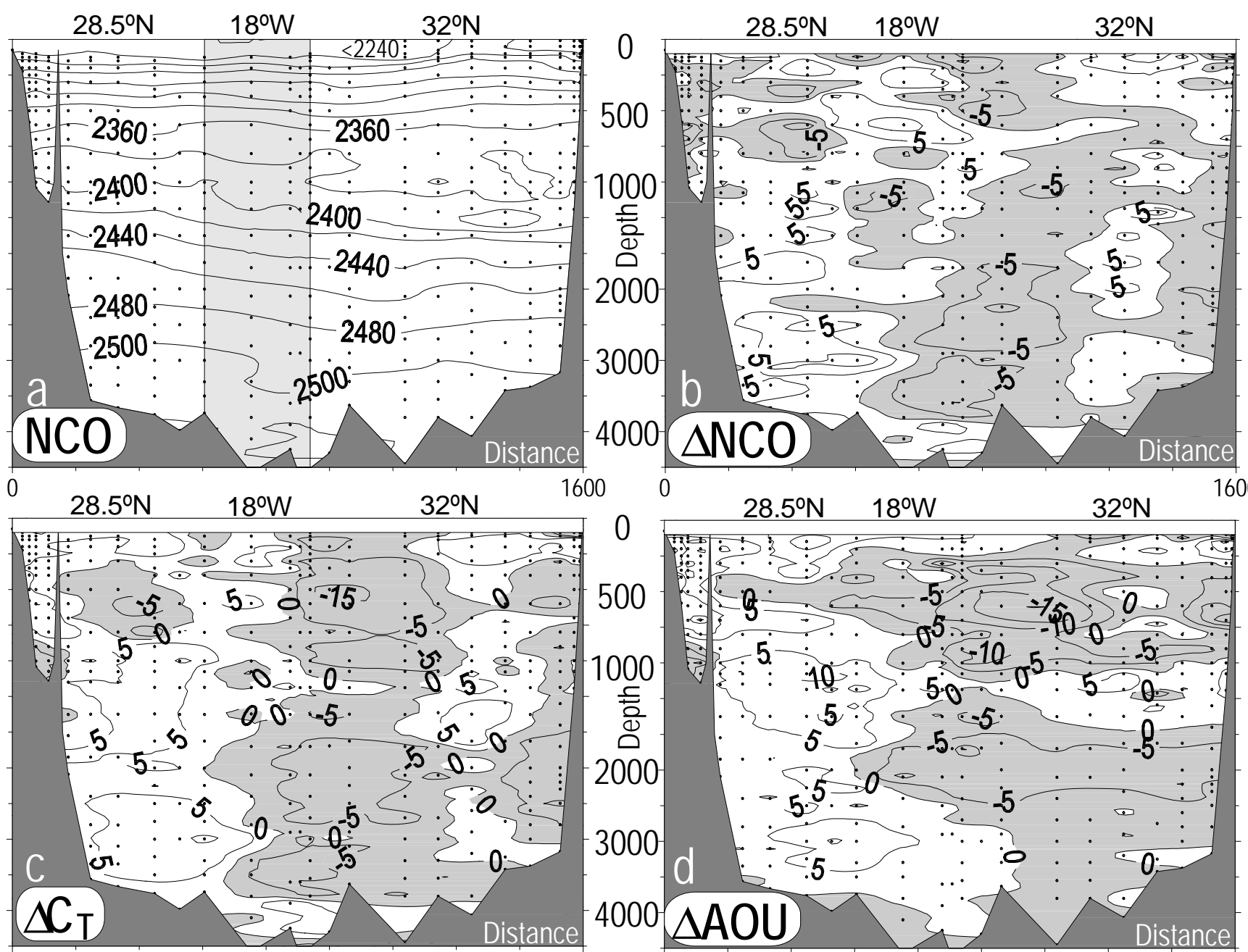

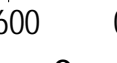

$0 \quad 28.5^{\circ} \mathrm{N} \quad 18^{\circ} \mathrm{W}$

1600
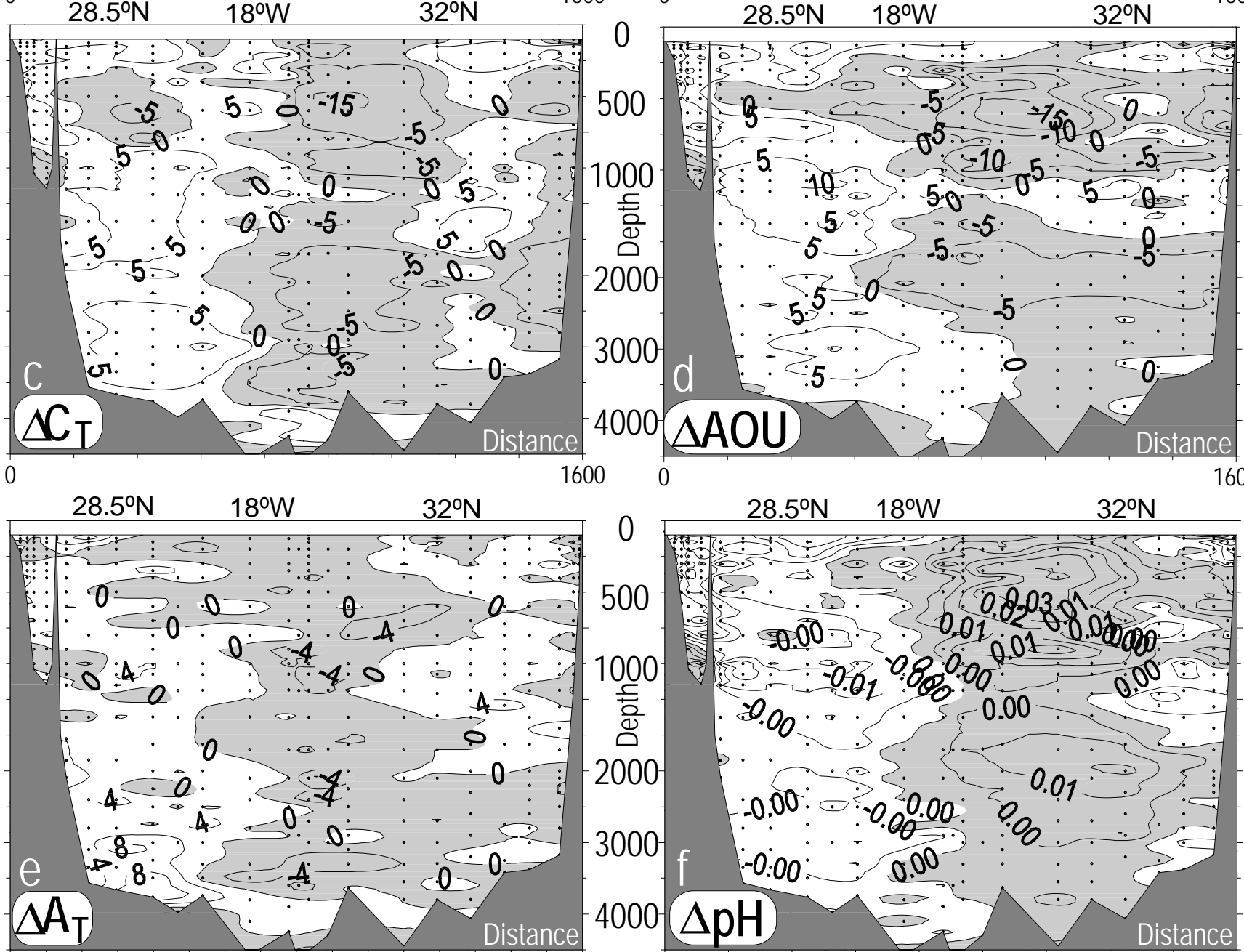

$1600 \quad 0$

$28.5^{\circ} \mathrm{N} \quad 18^{\circ} \mathrm{W}$

1600
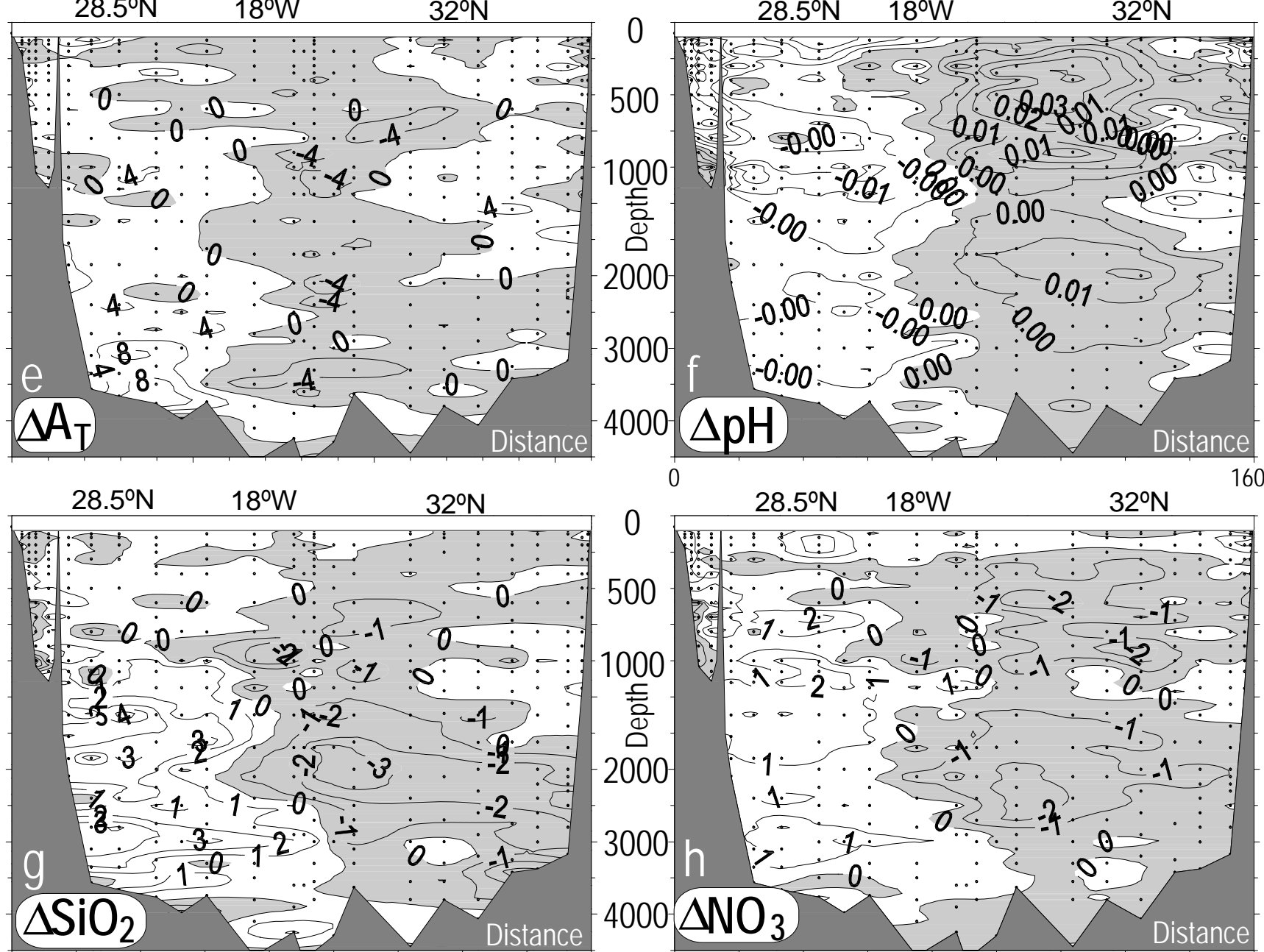
SiO
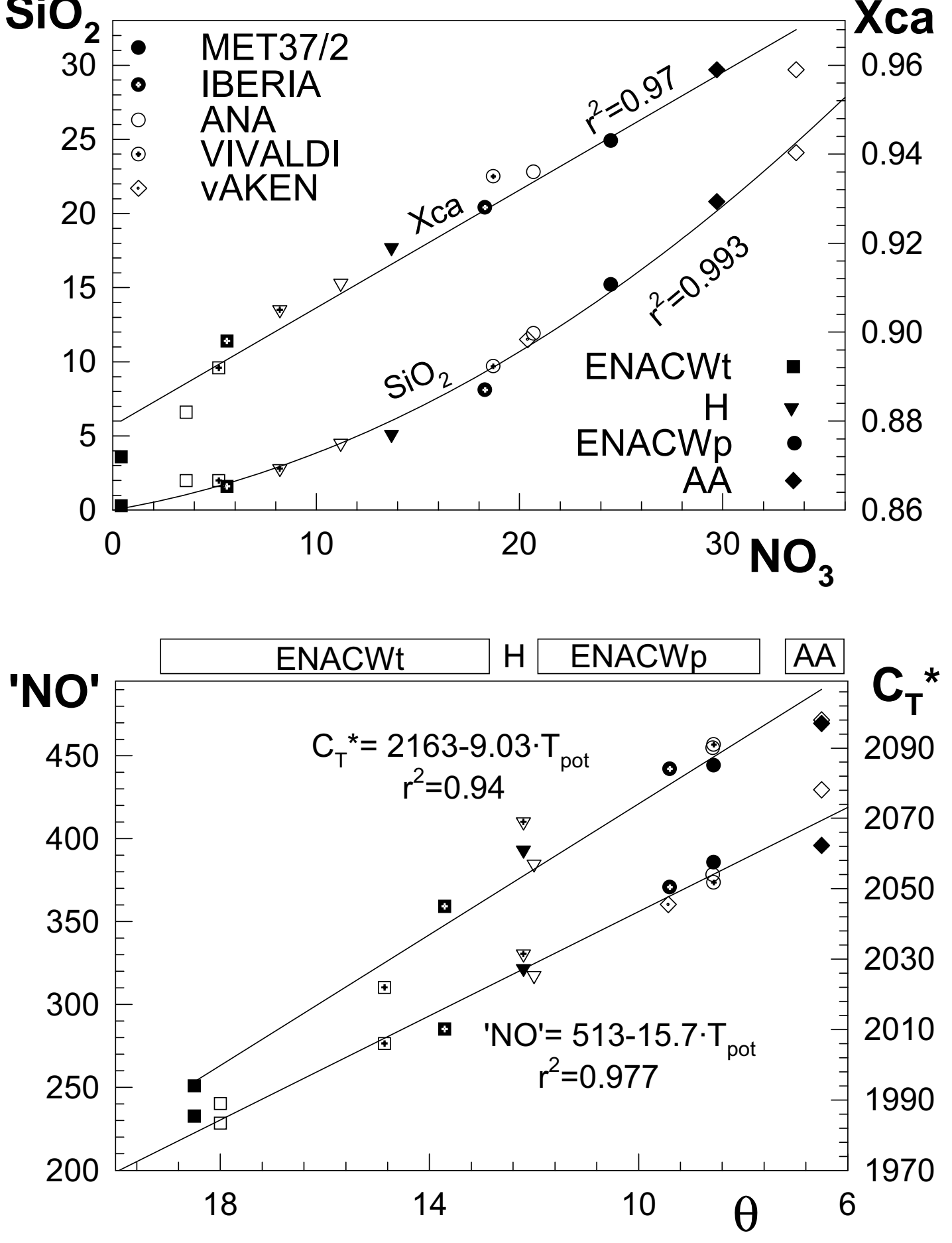